\title{
Multigene phylogeny of the scyphozoan jellyfish family Pelagiidae reveals that the common U.S. Atlantic sea nettle comprises two distinct species (Chrysaora quinquecirrha and C. chesapeakei)
}

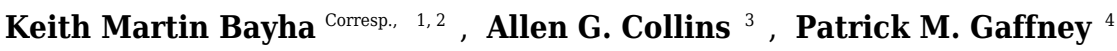 \\ 1 Invertebrate Zoology Department, Smithsonian Institution, National Museum of Natural History, Washington, DC, United States \\ 2 Department of Biological Sciences, University of Delaware, Newark, DE, United States \\ 3 National Systematics Laboratory of NOAA's Fisheries Service, Smithsonian Institution, Washington, DC, United States \\ ${ }^{4}$ College of Earth, Ocean and Environment, University of Delaware, Lewes, DE, United States \\ Corresponding Author: Keith Martin Bayha \\ Email address: bayhak@si.edu
}

Background. Species of the scyphozoan family Pelagiidae (e.g. Pelagia noctiluca, Chrysaora quinquecirrha) are well-known for impacting fisheries, aquaculture and tourism, especially for the painful sting they can inflict on swimmers. However, historical taxonomic uncertainty at the genus (e.g. new genus Mawia) and species levels hinders progress in studying their biology and evolutionary adaptations that make them nuisance species, as well as ability to understand and/or mitigate their ecological and economic impacts.

Methods. We collected nuclear (28S rDNA) and mitochondrial (cytochrome $c$ oxidase I [COI] and 165 rDNA) sequence data from individuals of all four pelagiid genera, including eleven of thirteen currently recognized species of Chrysaora. To examine species boundaries in the U.S. Atlantic sea nettle Chrysaora quinquecirrha, specimens were included from its entire range along the U.S. Atlantic and Gulf of Mexico coasts, with representatives also examined morphologically (macromorphology and cnidome). Results. Phylogenetic analyses show that the genus Chrysaora is paraphyletic with respect to other pelagiid genera. In combined analyses, Mawia, sampled from the coast of Senegal, is most closely related to Sanderia malayensis, and Pelagia forms a close relationship to a clade of Pacific Chrysaora species (C. achlyos, C. colorata, C. fuscescens and C. melanaster). C. quinquecirrha is polyphyletic, with one clade from the U.S. coastal Atlantic and another in U.S. Atlantic estuaries and Gulf of Mexico. These genetic differences are reflected in morphology, e.g., tentacle and lappet number, oral arm length and nematocyst dimensions. Caribbean sea nettles (Jamaica and Panama) are genetically similar to the U.S. Atlantic estuaries and Gulf of Mexico clade of $C$. quinquecirrha.

Discussion. Our phylogenetic hypothesis for Pelagiidae contradicts current generic 
definitions, revealing major disagreements between DNA-based and morphology-based phylogenies. A paraphyletic Chrysaora raises systematic questions at the genus level for Pelagiidae; accepting the validity of the recently erected genus Mawia, as well as past genera, will require the creation of additional pelagiid genera. Historical review of the species-delineating genetic and morphological differences indicates that Chrysaora quinquecirrha Desor 1848 applies to the US Coastal Atlantic Chrysaora species (US Atlantic sea nettle), while the name $C$. chesapeakei Papenfuss 1936 applies to the US Atlantic estuarine and Gulf of Mexico Chrysaora species (US Atlantic bay nettle). We provide a detailed redescription, with designation of a neotype for $C$. chesapeakei, and clarify the description of $C$. quinquecirrha. Since Caribbean Chrysaora are genetically similar to $C$. chesapeakei, we provisionally term them Chrysaora c.f. chesapeakei. The presence of $M$. benovici off the coast of western Africa provides a potential source region for jellyfish introduced into the Adriatic Sea in 2013. 
2 Multigene phylogeny of the scyphozoan jellyfish family Pelagiidae reveals that the common U.S.

3 Atlantic sea nettle comprises two distinct species (Chrysaora quinquecirrha and C. chesapeakei)

4

Bayha, Keith Martin ${ }^{1,2^{*}}$, Allen G. Collins ${ }^{3}$, and Patrick M. Gaffney ${ }^{4}$

6

$7 \quad{ }^{1}$ National Museum of Natural History, Smithsonian Institution, Invertebrate Zoology

8 Dept., $10^{\text {th }}$ St. and Constitution Ave. NW, Washington, DC, 20013, USA

$9{ }^{2}$ University of Delaware, Department of Biological Sciences, Newark, DE, 19716, USA

$10{ }^{3}$ National Systematics Laboratory of NOAA's Fisheries Service, National Museum of

11 Natural History, Smithsonian Institution, PO Box 37012, Washington, DC, 20013, USA

$13{ }^{4}$ University of Delaware, College of Earth, Ocean \& Environment, 700 Pilottown Rd., Lewes, DE, 19958, USA

*Corresponding Author (bayhak@si.edu; kmbayha@gmail.com)

16

17 Short Title: U.S. Atlantic sea nettle is two species 
19 ABSTRACT

20 Background. Species of the scyphozoan family Pelagiidae (e.g. Pelagia noctiluca, Chrysaora

21 quinquecirrha) are well-known for impacting fisheries, aquaculture and tourism, especially for

22 the painful sting they can inflict on swimmers. However, historical taxonomic uncertainty at the

23 genus (e.g. new genus Mawia) and species levels hinders progress in understanding their biology

24 and the evolutionary adaptations that make them nuisance species, as well as ability to

25 understand and/or mitigate their ecological and economic impacts. Methods. We collected

26 nuclear (28S rDNA) and mitochondrial (cytochrome $c$ oxidase I [COI] and $16 S$ rDNA) sequence

27 data from individuals of all four pelagiid genera, including eleven of thirteen currently

28 recognized species of Chrysaora. To examine species boundaries in the U.S. Atlantic sea nettle

29 Chrysaora quinquecirrha, specimens were included from its entire range along the U.S. Atlantic

30 and Gulf of Mexico coasts, with representatives also examined morphologically

31 (macromorphology and cnidome). Results. Phylogenetic analyses show that the genus

32 Chrysaora is paraphyletic with respect to other pelagiid genera. In combined analyses, Mawia,

33 sampled from the coast of Senegal, is most closely related to Sanderia malayensis, and Pelagia

34 forms a close relationship to a clade of Pacific Chrysaora species (C. achlyos, C. colorata, C.

35 fuscescens and C. melanaster). C. quinquecirrha is polyphyletic, with one clade from the U.S.

36 coastal Atlantic and another in U.S. Atlantic estuaries and Gulf of Mexico. These genetic

37 differences are reflected in morphology, e.g., tentacle and lappet number, oral arm length and

38 nematocyst dimensions. Caribbean sea nettles (Jamaica and Panama) are genetically similar to

39 the U.S. Atlantic estuaries and Gulf of Mexico clade of C. quinquecirrha. Discussion. Our

40 phylogenetic hypothesis for Pelagiidae contradicts current generic definitions, revealing major

41 disagreements between DNA-based and morphology-based phylogenies. A paraphyletic 
42 Chrysaora raises systematic questions at the genus level for Pelagiidae; accepting the validity of

43 the recently erected genus Mawia, as well as past genera, will require the creation of additional

44 pelagiid genera. Historical review of the species-delineating genetic and morphological

45 differences indicates that Chrysaora quinquecirrha Desor 1848 applies to the US Coastal

46 Atlantic Chrysaora species (US Atlantic sea nettle), while the name C. chesapeakei Papenfuss

471936 applies to the US Atlantic estuarine and Gulf of Mexico Chrysaora species (US Atlantic

48 bay nettle). We provide a detailed redescription, with designation of a neotype for $C$.

49 chesapeakei, and clarify the description of C. quinquecirrha. Since Caribbean Chrysaora are

50 genetically similar to C. chesapeakei, we provisionally term them Chrysaora c.f. chesapeakei.

51 The presence of $M$. benovici off the coast of western Africa provides a potential source region

52 for jellyfish introduced into the Adriatic Sea in 2013. 


\section{INTRODUCTION}

54 Scyphozoan jellyfishes (Cnidaria, Class Scyphozoa), which include the conspicuous

55 moon, lion's mane and sea nettle jellyfishes, exhibit significant and widespread economic and

56 ecological impacts on a wide array of marine and estuarine communities. Jellyfish aggregations,

57 blooms and swarms damage economically important fisheries, close tourist beaches by stinging

58 swimmers, clog intakes of coastal power and desalination plants, invade ecosystems and can

59 affect oxygen levels when mass numbers of carcasses are deposited (Arai 1997; Purcell, Uye \&

60 Lo 2007; Richardson et al. 2009; Bayha \& Graham 2014; Qu et al. 2015). On the other hand,

61 jellyfish serve important roles as major prey items for some fish and sea turtles, in carbon

62 capture and advection to the Deep Ocean, as important microhabitat for fish, invertebrates and

63 symbiotic algae, and as economic resources for humans (as food and therapeutic compounds)

64 (Omori \& Nakano 2001; Castro, Santiago \& Santana-Ortega 2002; Arai 2005; Houghton et al.

65 2006; Lynam \& Brierley 2007; Ohta et al. 2009; Lebrato et al. 2012; Diaz Briz et al. 2017).

66 Recent attention given to large medusae blooms has led to speculation that anthropogenic events

67 are driving global increases in jellyfish bloom magnitudes, though long-term data sets are still

68 equivocal on this point (Richardson et al. 2009; Brotz \& Pauly 2012; Condon et al. 2013).

Despite their importance, evolutionary and taxonomic relationships of even some of the

70 most recognizable scyphozoan species remain unsettled, which can impede our abilities to

71 effectively study, predict and mitigate the ecological and economic effects of these nuisance

72 species. Recent systematics studies have directly challenged taxonomic relationships at all levels.

73 A mitogenomic analysis recently challenged the placement of the order Coronatae, such as

74 Periphylla, within Scyphozoa (Kayal et al. 2013; but see Kayal et al. 2017) and the new family

75 Drymonematidae was created based on morphological, molecular and life history data (Bayha \& 
76 Dawson 2010; Bayha et al. 2010). Studies employing molecular and/or morphological data have

77 revealed novel species in multiple scyphozoan genera, including the moon jellyfish Aurelia

78 (Dawson \& Jacobs 2001; Schroth et al. 2002; Dawson 2003), the genus Drymonema (Bayha \&

79 Dawson 2010), the upside down jellyfish Cassiopea (Holland et al. 2004), and the lion's mane

80 jellyfish Cyanea (Dawson 2005; Kolbasova et al. 2015). Many of these studies have uncovered

81 unrecognized jellyfish invasions and clarified evolutionary relationships in the group (from order

82 to species level) vital to understanding their ecological and economic impacts, and elucidating

83 the evolution of traits that permit these impacts.

84 The scyphozoan family Pelagiidae (Gegenbaur 1856), currently made up of four genera

85 (Pelagia, Chrysaora, Sanderia and Mawia), contains some of the world's most notorious

86 blooming jellyfish. The geographically widespread mauve stinger (Pelagia noctiluca) forms

87 dense aggregations that heavily impact aquaculture, fisheries and tourism along the North Sea

88 and Mediterranean Sea (Canepa et al. 2014). Recently, a species found for the first time in the

89 Mediterranean was described and assigned first to the genus Pelagia (Piraino et al. 2014), but

90 later to the novel genus Mawia, based on molecular and morphological data (Avian et al. 2016).

91 Blooms of the jellyfish Chrysaora fulgida (previously identified as C. hysoscella) have increased

92 over past decades in the Northern Benguela current on the west coast of Africa, coinciding with

93 decreased fish catches and general breakdown of beneficial trophic interactions as compared to

94 nearby ecosystems not jellyfish-dominated (Lynam et al. 2006; Flynn et al. 2012; Roux et al.

95 2013). Likewise, blooms of very large Chrysaora plocamia medusae form off the coast of Peru,

96 interfering with fisheries, aquaculture and power plants by clogging nets, seines and water

97 intakes (Mianzan et al. 2014). 
A species of special note is the U.S. Atlantic sea nettle Chrysaora quinquecirrha (Desor

99

100

101

102

103

104

105

106

107

108

109

110

111

112

113

114

115

116

117 Chrysaora and Pelagia, Agassiz (1862) erected a new genus, Dactylometra, within the family.

118 Among other characters, Agassiz (1862) classified genera based on tentacle and lappet numbers:

119 Pelagia (8 tentacles, 16 marginal lappets), Chrysaora (24 tentacles, 32 marginal lappets) and

120 Dactylometra (40 tentacles, 48 marginal lappets). Kishinouye (1902) subsequently described the 
121 genus Kuragea (56 tentacles, 64 marginal lappets) and Goette (1886) described Sanderia (16

122 tentacles, 32 lappets and 16 rhopalia). To the genus Dactylometra, Agassiz (1862) added

123 Pelagia quinquecirrha (Desor 1848) from Nantucket Bay (MA) and Chrysaora lactea

124 (Eschscholtz 1829) from Rio de Janeiro. Based on established generic definitions, Piraino et al.

125 (2014) placed an undescribed, presumably non-indigenous Mediterranean pelagiid, Pelagia

126 benovici, in the genus Pelagia. However, Avian et al. (2016) created the novel genus Mawia for

127 this new species (Mawia benovici) based on fine-scale morphological characters (tentacle, gonad

128 and basal pillar morphology) and molecular differences from other pelagiid genera included in a

129 lightly sampled phylogenetic analysis of Pelagiidae.

130 Not long after Agassiz erected Dactylometra, Dactylometra quinquecirrha served to cast

131 doubt on pelagiid generic discrimination. Bigelow (1880) recognized that some brackish water

132 (e.g. Chesapeake Bay) D. quinquecirrha matured at 24 tentacles (a character of Chrysaora)

133 rather than 40 (a character of Dactylometra), something Mayer (1910), saw as the "Chrysaora"

134 stage in their development to the "Dactylometra" stage. Stiasny (1930) also cast doubt on the

135 ability to effectively differentiate Chrysaora and Dactylometra. As a result, Kramp (1955)

136 reasoned Dactylometra and Kuragea to be merely developmental stages and subsumed both

137 within the genus Chrysaora (Eschscholtz 1829), since it has taxonomic priority. Calder (1972)

138 determined that C. quinquecirrha went through stages of one to more than seven tentacles per

139 octant, often in the same geographic region, supporting the contentions of Mayer (1910) and

140 Kramp (1955). A morphology-based phylogeny of the Pelagiidae (Gershwin \& Collins 2002)

141 indicated two groups coinciding with the previous genera Dactylometra and Chrysaora, but

142 noted that the weak phylogenetic support would make resurrecting the genus Dactylometra

143 premature. Another morphology-based phylogeny (Morandini \& Marques 2010) found support 
144 for a Dactylometra clade based on tentacle and lappet number, but noted that this would require

145 many Chrysaora species to have their own genera. A robust phylogenetic hypothesis of

146 relationships within Pelagiidae based on comprehensive taxon sampling is an important step

147 toward removing taxonomic confusion at the genus and species-levels, including assessing the

148 taxonomic status of the new genus Mawia (Avian et al. 2016) and clarifying taxonomic questions

149 related to C. quinquecirrha.

150 In order to examine evolutionary relationships and taxonomic boundaries in the family

151 Pelagiidae, with special focus on the genus Chrysaora and the species C. quinquecirrha, we

152 collected nuclear (large subunit ribosomal rDNA) and mitochondrial (cytochrome $c$ oxidase I

153 and large subunit ribosomal rDNA) sequence data from individuals representing all four extant

154 genera (Chrysaora, Mawia, Pelagia and Sanderia), including eleven currently recognized

155 species of Chrysaora and one species each of Mawia (M. benovici), Pelagia (Pelagia noctiluca)

156 and Sanderia (S. malayensis). To further examine the taxonomy of the U.S. Atlantic sea nettle

157 Chrysaora quinquecirrha, specimens were included from its entire range along the U.S. Atlantic

158 and Gulf of Mexico coasts (estuarine and coastal), taking care to sample all recognized

159 morphotypes, with representatives also examined morphologically (macromorphology and 160 cnidome).

161

162 MATERIALS AND METHODS

163 Sample Collection

164 Specimens were collected in the field or at public aquaria husbandry facilities, either by

165 the authors or others with extensive knowledge of Scyphozoa, in an effort to collect as many

166 species of Chrysaora as possible, as well as representative species of Pelagia, Mawia and 
167 Sanderia (Table 1; Figure 1). An unknown and unidentified pelagiid specimen was collected

168 from Dakar, Senegal and was accompanied by a photograph that did not allow for specific

169 identification (Figure S1). For Chrysaora quinquecirrha, samples were collected from 10

170 different sites along the Atlantic and Gulf of Mexico coasts (Table 1; Figure 2), covering both

171 coastal and estuarine environments, with the intention of capturing as many structural and color

172 morphotypes as possible (Figure 3). Both white (Table 1: NF1-NF3) and red-striped (Table 1:

173 NF4-NF5) color morphs (Figure 3C, D) were collected from Norfolk, VA (NF). In all cases, a

174 small piece of gonad, tentacle or oral arm tissue was excised and preserved in $80 \_99 \%$ ethanol

175 or DMSO-NaCl solution (Dawson, Raskoff \& Jacobs 1998). Where possible for some sites

176 (Table S1), individuals were also preserved in 4\% buffered formalin and seawater for later

177 morphological analyses. Additional published pelagiid sequences were included in the final data 178 set (Table 2).

179

180

DNA extraction, PCR amplification and DNA sequencing

181

Genomic DNA was extracted from preserved tissue samples by CTAB

182 (cetyltrimethylammonium bromide) methods (Ausubel et al. 1989) and stored at $-20^{\circ} \mathrm{C}$.

183 Polymerase chain reaction (PCR) amplifications targeted three genetic regions: mitochondrial

184 large subunit ribosomal DNA $(16 S)$ and cytochrome $c$ oxidase subunit I (COI) and nuclear large 185 subunit ribosomal DNA (28S) using primers shown in Table S2. We chose genetic regions that

186 have been useful in examining species boundaries and/or examining genus and family level

187 relationships in the Scyphozoa (Dawson \& Jacobs 2001; Schroth et al. 2002; Holland et al. 2004;

188 Dawson 2005; Dawson, Gupta \& England 2005; Bayha \& Dawson 2010). Reaction conditions

189 for $16 S$ consisted of one cycle of $94^{\circ} \mathrm{C}$ for 180 seconds (s), then 38 cycles of $94^{\circ} \mathrm{C}$ for $45 \mathrm{~s}, 50^{\circ} \mathrm{C}$ 
190 for $60 \mathrm{~s}$ and $72^{\circ} \mathrm{C}$ for $75 \mathrm{~s}$, followed by a final step of $72^{\circ} \mathrm{C}$ for $600 \mathrm{~s}$ and storage at $4^{\circ} \mathrm{C}$.

191 Reaction conditions for $\mathrm{COI}$ consisted of one cycle of $94^{\circ} \mathrm{C}$ for $180 \mathrm{~s}$, followed by two cycles of

$1929^{\circ} \mathrm{C}$ for $45 \mathrm{~s}, 46^{\circ} \mathrm{C}$ for $60 \mathrm{~s}$ and $72^{\circ} \mathrm{C}$ for $75 \mathrm{~s}$, two cycles of $94^{\circ} \mathrm{C}$ for $45 \mathrm{~s}, 47^{\circ} \mathrm{C}$ for $60 \mathrm{~s}$ and

$19372^{\circ} \mathrm{C}$ for $75 \mathrm{~s}$ and 35 cycles of $94^{\circ} \mathrm{C}$ for $45 \mathrm{~s}, 48^{\circ} \mathrm{C}$ for $60 \mathrm{~s}$ and $72^{\circ} \mathrm{C}$ for $75 \mathrm{~s}$, followed by a final

194 step of $72^{\circ} \mathrm{C}$ for $600 \mathrm{~s}$ and storage at $4^{\circ} \mathrm{C}$. Lastly, reactions conditions for $28 S$ consisted of $94^{\circ} \mathrm{C}$

195 for $180 \mathrm{~s}$, then 38 cycles of $94^{\circ} \mathrm{C}$ for $45 \mathrm{~s}, 48^{\circ} \mathrm{C}$ for $60 \mathrm{~s}$ and $72^{\circ} \mathrm{C}$ for $90 \mathrm{~s}$, followed by $72^{\circ} \mathrm{C}$ for

196600 s then storage at $4^{\circ} \mathrm{C}$. Successful amplification was evaluated by running the PCR products

197 on a $\%$ agarose gel. PCR amplicons were directly sequenced using a combination of sequencing

198 primers (Table S2). DNA sequencing was performed by University of Washington High

199 Throughput Genomics Unit (Seattle, WA) or Beckman-Coulter Genomics (Danvers, MA).

200 Sequences were assembled using Lasergene SeqMan Pro v. 8.1.5 (DNAStar, Inc.) and then

201 compared to the GenBank nucleotide database using BLASTn or BLASTx (Altschul et al. 1997)

202 to confirm identity of sequenced region and ensure no sequencing errors that affected amino acid

203 reading frames $(C O I)$. All DNA sequences were submitted to NCBI GenBank (MF141552-

204 MF141718; MF167556-MF167568).

205

206 Phylogenetic Reconstruction

207 For all analyses, Cyanea capillata (Blomsterdalen, Norway) was used as the outgroup

208 because it was shown to be among those scyphozoans least diverged from Pelagiidae (Bayha et

209 al. 2010). COI sequences were aligned using CLUSTALX v2.1 (Larkin et al. 2007) under default

210 parameters, and checked by eye using their amino acid translations as a guide. $16 \mathrm{~S}$ and $28 \mathrm{~S}$

211 sequences were aligned using MAAFT v7.245 employing the E-INS-I strategy (Katoh \&

212 Standley 2013), since this strategy has been demonstrated to be effective for loci containing 
213 conserved motifs embedded within hypervariable regions (Katoh \& Toh 2008). Hypervariable

214 regions of questionable alignment were removed from the MAAFT alignments using GBlocks

215 v0.91b (Castresana 2000) under default parameters, except that gapped positions were set to half.

216 Phylogenetic analyses were run under Maximum Likelihood (ML) and Bayesian

217 Inference (BI) frameworks for COI, $16 S, 28 S$ and a combined dataset. Maximum Likelihood

218 phylogenetic trees were constructed using PhyML v3.0 (Guindon et al. 2010), employing the

219 best-fit substitution models assessed using jModelTest v2.1.7 (Darriba et al. 2012) under Akaike

220 (AIC) and Bayesian (BIC) Information Criteria, as well as Decision Theory Performance-Based

221 Selection (DT). For $C O I(\mathrm{TPM} \mu \mathrm{f}+\mathrm{I}+\mathrm{G}), 16 S(\mathrm{TIM} 2+\mathrm{I}+\mathrm{G})$, and combined $(\mathrm{GTR}+\mathrm{I}+\mathrm{G})$ datasets,

222 selection criteria were unanimous, while BIC and DT chose TrNef $+\mathrm{I}+\mathrm{G}$ for $28 S$. A 1000

223 bootstrap replicate analysis was performed in PhyML to obtain node support values. Bayesian

224 Inference (BI) of gene phylogenies was carried out using MrBayes v3.2.6 (Ronquist et al. 2012).

225 The same model of nucleotide evolution $(\mathrm{GTR}+\mathrm{I}+\mathrm{G}$, with gamma distribution approximated by

226 four discrete categories) was assumed for all analyses, since it is not possible to implement the

227 less complicated models used in the ML tree searches (in the cases of $16 S$ and $C O I$ ). For each

228 dataset, two independent MCMC runs were conducted until the standard deviation of split

229 frequencies decreased to less than 0.01 (I6S: 6,481,000; COI: 19,608,000; 28S: 1,390,000;

230 combined: 1,002,000) generations, sampling every 1,000. The number of generations was

231 determined by assessment of convergence using the minimum Estimated Sample Size and

232 Potential Scale Reduction Factor, as implemented in MrBayes. Posterior probabilities were

233 calculated using all trees other than the first $25 \%$, which were discarded as "burnin". All trees

234 were visualized using Figtree v1.4.2 (Rambaut 2014) and redrawn for presentation using Adobe

235 Illustrator CC v19.1.0 (Adobe Systems, Inc.). Mean interclade and intraclade, as well as 
236 minimum interclade sequence divergence values (Kimura 2-parameter) were determined using

237 MEGAv7.0.14 (Kumar, Stecher \& Tamura 2016) and nucleotide statistics calculated in Seaview 238 v4.6 (Gouy, Guindon \& Gascuel 2010).

239

\section{Morphological Analysis of Chrysaora quinquecirrha}

While our study did not include a family-wide morphological analysis, we did perform morphological analyses on jellyfish identified as Chrysaora quinquecirrha from the U.S. Atlantic and Gulf of Mexico coasts. We examined a total of 57 formalin-preserved samples we 244 collected from Charlestown Pond (RI), Cape Henlopen (DE), Rehoboth Bay (DE), York River

245 (VA), Charleston (SC) and Dauphin Island (AL) (Table S1). In addition, we examined a total of 24663 individuals housed at the Smithsonian Institution National Museum of Natural History 247 (USNM) that were collected from the U.S. Atlantic and Gulf of Mexico coasts and identified as 248 Chrysaora quinquecirrha or Chrysaora sp. (Table S1). We examined morphological characters 249 (and their states) previously employed for Pelagiidae (Gershwin \& Collins 2002) that pertained 250 to the medusa stage, with the addition of maximum oral arm length (Table 3 ). In addition, a total 251 of 35 individuals that were examined morphologically, but not included in the phylogenetic 252 analyses, were assigned to molecular species/clades using mitochondrial $16 S$ sequence data 253 collected using the established procedure described above (Table S1).

\section{Cnidome of Chrysaora quinquecirrha}

Lastly, we examined the cnidome of multiple specimens originally identified as 
259 Nematocyst terminology followed convention used in previous studies (Weill 1934; Calder

260 1971; Calder 1974a; Östman \& Hydman 1997; Morandini \& Marques 2010) in defining four

261 different nematocyst types: holotrichous A-isorhiza, holotrichous a-isorhiza, holotrichous O-

262 isorhiza and heterotrichous microbasic rhopaloid. In agreement with Morandini \& Marques

263 (2010), we use the term heterotrichous microbasic rhopaloid, recognizing that there are likely at

264 least two nematocysts that cannot be effectively delineated based on basic light microscopy, as

265 shown in other previous work (Sutton \& Burnett 1969).

266 In all cases, formalin-preserved tentacle tissue was homogenized in distilled water in 1.5

$267 \mathrm{~mL}$ microcentrifuge tubes and nematocysts were examined using differential interference

268 contrast microscopy (DIC). A small piece of formalin-fixed tentacle tissue was homogenized in

$269100 \mathrm{uL}$ of distilled water in a $1.5 \mathrm{uL}$ tube using a plastic microcentrifuge pestle until little visible

270 intact tissue remained. A small drop was then placed on a slide under cover slip and examined at

$27160 \mathrm{X}$ in DIC using an Olympus BX63 microscope, with photographs taken using an Olympus

272 DP80 camera run by CellSens Dimension 1.13 (Olympus Life Science, Inc.).

273 A total of 15 individuals were examined for nematocyst size measurements (Table S1). In

274 all cases, 10 samples of each nematocyst type were photographed and later measured using

275 CellSens Dimension 1.13 computer program for length and width. Linear Discrimination

276 Analysis (LDA) was used to determine whether species could be distinguished on the basis of

277 nematocyst measurements using the lda routine in the R package MASS (Venables \& Ripley 278 2002).

279 A total of 10 individuals were examined for nematocyst diversity (Table S1). Since 280 initial estimates indicated that nematocyst diversity varied by tentacle region, nematocyst counts 281 were done from three tentacle regions for each individual: proximal (near the base of the 
282 tentacle), medial (in the middle of the tentacle) and distal (at the end of the tentacle). For each

283 region, the first 200 nematocysts were photographed and categorized according to nematocyst

284 type. Only lone nematocysts were enumerated, with any nematocysts still adhering to epithelial

285 tissue ignored, since smaller nematocysts (e.g. a-isorhizas) could be obscured. In order to

286 examine any differences in nematocyst diversity between different tentacle regions (distal,

287 medial, proximal), a mosaic plot showing the relative proportions of nematocyst types in the

288 various regions was made using the R package $v c d$ version 1.4-3 (Meyer, Zeileis \& Hornik

289 2016). In order to visualize differences in proportions of nematocyst types (four types, three

290 regions) between the two species we conducted non-metric multidimensional scaling of the

291 Euclidean distance matrix using the isoMDS routine in the R package MASS (Venables \&

292 Ripley 2002).

293

294 RESULTS

\section{Sequence Data Characteristics and Phylogenetic Inference}

The COI dataset consisted of 73 sequences, 59 of which are new. All sequences were 616

297 bp in length. The $16 S$ data set was made up of 67 sequences, including 60 new sequences and 7

298 published sequences. New complete sequences varied in length from 598 base pairs (bp) for $C$.

299 lactea to $608 \mathrm{bp}$ (C. chinensis). The MAAFT-aligned data set (included published sequences)

300 was $628 \mathrm{bp}$, but the dataset was truncated to 582 bp (95.7\%) after treatment with GBlocks. The

$30128 S$ dataset included 35 sequences, including 24 new sequences and 11 published sequences.

302 New sequences ranged in size from 998 (C. chinensis) to 1018 bp (C. africana). The MAFFT

303 alignment (which included published sequences) was $1027 \mathrm{bp}$, but the final data set was $1015 \mathrm{bp}$

304 (98.8\%) after removal of regions via GBlocks. 
All phylogenetic analyses (COI, $16 \mathrm{~S}, 28 \mathrm{~S}$ and combined) revealed similar terminal

306

307

308

309

310

311

312

313

314

315

316

317

318

319

320

321

322

323

324

325

326

327

clades, but they differed in the resolution of relationships among them. The combined analysis

provided the best resolution (smallest proportion of polytomous nodes) and highest support values for evolutionary relationships (Figures 4-7). In all analyses, Chrysaora is revealed as

paraphyletic with respect to species of Sanderia, Pelagia, and Mawia. In the combined analyses, Mawia benovici is most closely related to Sanderia malayensis (Bayesian support 100 /

maximum likelihood support 100), with these two species forming a close relationship with $C$.

africana and C. pacifica in the combined (88/67) and $28 S$ trees (100/61) (Figures 6-7). Except

for the COI tree, Pelagia noctiluca formed a close relationship with a clade of Pacific jellies $(C$.

achlyos, C. colorata, C. fuscescens and C. melanaster) with high support values (combined:

100/99; 16S: 100/92; 28S: 82/58) (Figures 5-7). For the combined analyses (100/100) and $28 S$

(100/100), a highly supported clade was composed of Atlantic species, including $C$.

quinquecirrha, C. lactea, C. plocamia, C. fulgida, C. hysoscella, C. chesapeakei [see Discussion] and the Caribbean Chrysaora, while this clade was less supported for COI (100/61) and $16 S$ (75/60) (Figures 4-7). Chrysaora fulgida (NAM), C. plocamia (PMA) and C. hysoscella (IRE) formed a closely related group in all analyses with high support values (combined: 100/100;28S: 100/99; COI: 100/94; 16S: 100/83). For sequences taken from Piraino et al. (2014) only, nuclear $28 S$ sequences for M. benovici from the Mediterranean (ADR) occurred in the distantly related clade for P. noctiluca from the Atlantic (OVA), and a P. noctiluca from the Mediterranean (TYR) occurred in the distantly related clade for M. benovici from the Mediterranean (ADR) (Figure 6).

At the species level, our analyses highlighted multiple species boundaries, and showed the samples identified as $C$. quinquecirrha to be polyphyletic. In all analyses, C. quinquecirrha 
328 sequences fell into two distinct, highly diverged clades (Figures 4-7; Tables S3-S5), with one

329 clade (C. chesapeakei - see Discussion and Systematics) made up of animals from U.S. Atlantic

330 estuaries and the Gulf of Mexico animals and another (C. quinquecirrha - see Discussion and

331 Systematics) made up of U.S. coastal Atlantic animals. Caribbean Chrysaora (Jamaica and

332 Panama) formed a clade closely related to C. chesapeakei in all analyses (Figures 4-7).

333 Aquarium animals previously identified as C. melanaster (AQA) were genetically distinct from

334 C. melanaster collected from the Bering Sea (BER) in all analyses where both were included

335 (Figures 4-6) and formed a clade with Chrysaora pacifica collected from South Korea (KOR)

336 and Japan (KYO) for COI and/or 16S. While aquarium collected C. chinensis formed a well-

337 supported clade with field collected C. chinensis (MAL), analyses differed in where this species

338 fell out in the trees (Figures 4-7). The unknown pelagiid collected from the western African coast

339 (SEN) was nearly identical to the newly described M. benovici from the Mediterranean for COI

$340 \quad(0.0-0.3 \%$ difference) and $28 S(0.0-0.2 \%$ difference) (Figures 4,6$)$.

342 Macromorphological and Nematocyst Analyses

343 A total of 120 medusae (57 field collected and 63 museum specimens) (Table S1)

344 previously identified as C. quinquecirrha s.l. were examined for 19 quantitative and qualitative

345 macromorphological characters taken from Gershwin and Collins (2002) and one new to this

346 study (maximum oral arm length) (Table 3). Overall, three macromorphological characters

347 differed significantly: tentacle number, lappet number and maximum oral arm length vs. bell

348 diameter (Table 3). Animals collected from the estuarine Atlantic and all Gulf of Mexico sites

349 (Table S1) had an average of 3.07 +/- 0.07 (95\% CI) tentacles per octant, excluding two aberrant

350 individuals (6 and 4.625-see Discussion) (Figure 8A; Table 3). In all instances when there were 
351 more than three tentacles per octant (excluding aberrant individuals above), the additional

352 tentacle(s) occurred between the secondary tentacles and the rhopalia (i.e. 3-2-1-2-3 octant

353 tentacle orientation) and were typically undeveloped, being of similar size to nearby lappets.

354 Animals collected from coastal regions along the U.S. Atlantic (Table S1) had an average of 5.28

$355+/-0.48(95 \% \mathrm{CI})$ tentacles per octant (Figure 8A; Table 3). Animals collected from the

356 estuarine Atlantic and all Gulf of Mexico sites (Table S1) had oral arms that were on average

$3573.00+/-0.39(95 \% \mathrm{CI})$ times as long as the bell diameter (Figure 8B; Table 3). Animals collected

358 from coastal regions of the U.S. Atlantic (Table S1) had oral arms that were on average $1.24+/$ -

$3590.27(95 \% \mathrm{CI})$ times as long as bell diameter (Figure 8B; Table 3). Of the animals that were

360 examined morphologically, a total of 38 individuals were also sequenced for $16 S$ to see which

361 Chrysaora clade they fell into (K2P sequence divergence $<1.5 \%$ ). Medusae examined

362 morphologically that fell into the $C$. chesapeakei phylogenetic clade had an average of $2.99+/-$

3630.03 tentacles per octant and oral arms that were $2.80+/-0.78(95 \% \mathrm{CI})$ times as long as bell

364 diameter on average, while all those that fell in the C. quinquecirrha clade had an average of

$3655.63+/-0.78$ tentacles per octant and oral arms that were on average $0.93+/-0.18(95 \% \mathrm{CI})$

366 times as long as bell diameter on average (Figure 8A, 8B).

367 We also studied the cnidome of medusae identified as C. quinquecirrha, examining the

368 measurements of individual nematocyst types (Figure 8C, S1), as well as the representation of

369 each type overall. Nematocyst measurements indicated significant grouping for holotrichous A-

370 isorhizas, but not for other types. A-isorhiza measurements (Length vs. Width) showed two

371 distinct groups, with one group containing only animals from U.S. Atlantic estuaries and the

372 Gulf of Mexico and the other containing coastal Atlantic animals (Figure 8C). All sequenced

373 animals in the smaller group (coastal Atlantic) were genetically similar to C. quinquecirrha for 
$37416 S$, while all jellyfish from the larger group (estuarine Atlantic and Gulf of Mexico) that were

375 sequenced for $16 S$ were genetically similar to $C$. chesapeakei (Figure 8C). For animals identified

376 as C. chesapeakei (based on habitat, macromorphology and/or genetics), LDA analysis indicated

377 that individual A-isorhiza measurements correctly identified species $97.8 \%$ of the time $(2.2 \%$ of

378 the time, they were incorrectly identified at C. quinquecirrha), while they were correctly

379 identified $100 \%$ of the time using the mean of 10 nematocyst measurements. For animals

380 previously identified as C. quinquecirrha (based on habitat, macromorphology and/or genetics),

381 LDA correctly identified them $100 \%$ of the time, whether one or 10 nematocysts were used.

382 Figure S2 (a-c) shows measurement graphs for a-isorhiza, O-isorhiza and heterotrichous

383 microbasic rhopaloids, all of which indicate no significant groupings of measurements.

$384 \quad$ Nematocysts from proximal, medial and distal regions were typed and counted (200 total)

385 for 10 individuals originally identified as C. quinquecirrha, chosen based on their previous

386 molecular and macromorphological groupings (five from each group). All in all, heterotrichous

387 microbasic rhopaloids were most frequent $(62.1 \pm 9.8 \%[95 \% \mathrm{CI}])$, followed by O-isorhizas

$388(13.4 \pm 5.0 \%[95 \% \mathrm{CI}])$, a-isorhizas $(12.4 \pm 2.8 \%[95 \% \mathrm{CI}])$ and A-isorhizas $(12.2 \pm 3.7 \%[95 \%$

$389 \mathrm{CI}]$ ). As pilot studies indicated, nematocyst type proportions were different for different tentacles

390 regions. While A-isorhizas and a-isorhizas were consistent over the entire tentacle, O-isorhizas

391 were overrepresented in proximal regions and heterotrichous microbasic rhopaloids were

392 overrepresented in the medial and distal regions (Figure S3A). Individuals varied considerably

393 in proportions of nematocyst types (Figure S3B). Individuals collected from coastal Atlantic

394 regions (circles) were generally clustered, including those genetically similar to

395 C. quinquecirrha, while those from estuarine Atlantic and Gulf of Mexico regions (squares) were

396 much more dispersed, as were those genetically similar to C. chesapeakei (Figure S3B). LDA 
397 was moderately effective in distinguishing species using overall nematocyst proportions (4 of 5

398 C. quinquecirrha and 3 of 5 C. chesapeakei correctly classified) and this was almost entirely due

399 to different proportions of A-isorhiza nematocysts. A-isorhiza proportions were significantly

400 different $(\mathrm{t}=3.623$, p-value $=0.0068)$, with $C$. chesapeakei individuals averaging $16.5 \pm 3.4 \%$ for

401 A-isorhiza and $C$ quinquecirrha cnidomes averaging $7.8 \pm 3.4 \%$.

402

403 DISCUSSION

404 Genus-level Systematic Inference

405 Our most robust phylogenetic hypothesis for Pelagiidae (Figure 7), based on the

406 combined data set, directly contradicts current generic definitions, as well as earlier

407 morphological-based phylogenies of the Pelagiidae. Both Gershwin \& Collins (2002) and

408 Morandini \& Marques (2010) considered Chrysaora to be reciprocally monophyletic with

409 respect to both Sanderia and Pelagia, with Sanderia in a basal position (Figure 9A, B). In

410 contrast, our analyses indicate that Chrysaora is paraphyletic with respect to Pelagia, Sanderia

411 and the newly erected Mawia (Figures 4-7, 9E). Mediterranean M. benovici is not in the

412 combined analysis, but our Senegal pelagiid (SEN) can be treated as M. benovici, based on COI

413 (Figure 4) and 28S (Figure 6) phylogenies (see below). Paraphyly of Chrysaora is not supported

414 in morphological or genetic analyses in Avian et al. (2016) (Figure 9C, D), but this is almost

415 certainly a result of incomplete taxon sampling. For example, their analysis based on combined

416 morphological and genetic data only included C. hysoscella (Mediterranean), while the $28 S$

417 dataset included a subset of sequences published at the time, (C. hysoscella, C. lactea, and C. c.f.

418 chesapeakei [see below]), all of which occur in a single clade in our analysis (Figure 7, 9E).

419 Including fewer published sequences gave the appearance of Chrysaora monophyly, which may 
420 have biased the establishment of Mawia. For instance, throughout Avian et al. (2016), Chrysaora

421 is often used as a singular entity (i.e. monophyletic), such as an entire section that examines

422 characters at the "genus level". This more readily allows for the conclusion of a novel genus

423 Mawia, as it sidesteps the difficult taxonomic questions raised by the paraphyly of Chrysaora.

424 That notwithstanding, in agreement with both Piraino et al. (2014) and Avian et al. (2016), our

425 analyses show M. benovici to be a close relative of Sanderia malayensis (Figures 4-7). Given the

426 stark morphological differences between Sanderia and Mawia (Piraino et al. 2014; Avian et al.

427 2016), this relationship is more than a bit surprising.

428 Our working hypothesis for the relationships within Pelagiidae (Figure 7, 9), especially

429 the paraphyletic Chrysaora, raises serious systematic questions for the genus level. To accept the 430 validity of Mawia, as well as previously established Pelagia and Sanderia, each of which can be 431 easily distinguished morphologically from those currently classified as Chrysaora, additional 432 genera would have to be erected within Pelagiidae in order to maintain monophyly of these 433 generic groupings. An initial matter would be to which clade should the genus Chrysaora should 434 be limited. Because the type species of Chrysaora is C. hysocella, the genus would best be 435 limited to the clade containing C. hysocella, C. fulgida, C. lactea, C. plocamia, C. quinquecirrha, 436 and C. chesapeakei (see below). This then would leave three other lineages in need of new 437 genera: 1) C. africana plus C. melanaster; 2) C. chinensis; and 3) C. achlyos, C. colorata and C. 438 fuscescens. The latter grouping (C. achlyos, C. colorata and C. fuscescens) has a close 439 relationship to Pelagia noctiluca (except for $C O I$ ) and there is genetic support for generic 440 designation. Unfortunately, we are currently aware of no clearly interpretable morphological 441 characters that could be invoked to diagnose this clade, or other Chrysaora lineages, as has been 442 the case in other studies seeking to reconcile jellyfish taxonomy based on morphology and 
443 molecular data (Dawson \& Martin 2001; Dawson 2003; Bayha \& Dawson 2010). Future study

444 will benefit from more detailed morphological analyses to identify additional characters that

445 could then be mapped onto molecular phylogenies (e.g. Figure 7), as well as greater taxonomic

446 sampling (e.g. two additional Chrysaora species accepted and two declared nomen dubium in

447 Morandini \& Marques (2010), more geographic samples of Pelagia and Sanderia). Both would

448 allow for better resolution to define genera and better explain their evolutionary relationships.

450 Interspecific Evolutionary Relationships and Geographic Patterns

451 While our molecular phylogenies bear almost no resemblance to the morphology-based

452 phylogenies within the currently defined genus Chrysaora (Gershwin \& Collins 2002; Morandini

$453 \&$ Marques 2010) (Figure 9), there are some relationships that occur in all phylogenies. All

454 phylogenies agree on a close relationship between C. achlyos and C. colorata (Figure 9A, B, E).

455 Our phylogeny is in general agreement with Morandini and Marques (2010) in delineating their

456 basal 'Pacific' group (C. achlyos, C. colorata, C. fuscescens, C. melanaster and C. plocamia),

457 except that our C. plocamia samples came from the Atlantic and occur in an 'Atlantic' group

458 (Table 1; Figure 1). Morandini and Marques (2010) reasoned that this basal group may have

459 provided ancient species that then invaded the Atlantic, splitting into various Atlantic groups.

460 Our combined phylogeny (Figure 7) is in general agreement, with Pacific Chrysaora species

461 generally occupying a more basal position in the tree compared to the Atlantic species. Major

462 disagreements with Morandini \& Marques (2010) include the placement of C. chinensis and $C$.

463 pacifica (both Pacific jellies) as closely related to C. quinquecirrha and C. lactea, with the $C$.

464 pacifica placement also a disagreement with Gershwin and Collins (2002). Likewise, the very

465 close relationship among C. fulgida, C. hysoscella and C. plocamia was not found in any of the 
466 morphological phylogenies (Figure 9), though C. hysoscella and C. plocamia were closely

467 related in Gershwin and Collins (2002).

468 One item of note here is our use of aquarium samples, which may be problematic where

469 they are not confirmed with field-collected specimens. Aquarium collected specimens of $C$.

470 pacifica (originally C. melanaster- see below) and C. chinensis are genetically confirmed, based

471 on published sequences from field-collected specimens of known geographical origin (Figures 4-

472 5). In addition, our aquarium-collected $C$. fuscescens is identical to published $16 S$ sequence of

473 field-collected animals from Vancouver Island, Canada (NCBI JX393256). However, $C$.

474 colorata, C. achlyos and S. malayensis are represented only by aquarium specimens and,

475 therefore, conclusions based on these sequences should be made with care, given questions

476 surrounding geographic provenance and any unnatural interbreeding that might occur in a the

477 aquarium system. Future studies incorporating field-collected specimens are necessary for

478 confirming or refuting relationships shown here.

479

480 Species-level Systematic Inference

481 Chrysaora quinquecirrha and C. chesapeakei

482

The most striking conclusion revealed from this study is that $C$. quinquecirrha, one of the 483 most studied and well-known U.S. Atlantic jellyfish, is made up of two distinct species, putting 484 to rest taxonomic disagreements going back more than 100 years. This finding is supported by 485 genetic (Figures 4-7), macromorphological (Figure 8A, 8B), and cnidome (Figure 8C) data. Chrysaora quinquecirrha occurred in two well-differentiated monophyletic groups, one

487 containing all animals from estuarine Atlantic (RI, NJ, RB, NF, PAM, GA) and Gulf of Mexico 488 (AL) regions and the other containing animals from coastal Atlantic regions (MA, CHP and 
489 OSC) (Figures 4-7). Average (COI: 13.1\%; 16S: 9.0\%; 28S: 2.5\%) and minimum (COI: 12.1\%;

490 16S: $8.4 \%$; $28 S: 2.4 \%$; Table S3-S5) sequence divergences are well above what has been seen as

491 delineating species in Aurelia (Dawson \& Jacobs 2001; Dawson, Gupta \& England 2005),

492 Cassiopea (Holland et al. 2004), Cyanea (Dawson 2005), and Drymonema (Bayha \& Dawson

493 2010). More convincing is the fact that C. fulgida from Namibia (NAM), C. plocamia from

494 Argentina (ARG) and C. hysoscella from Ireland (IRE) occur between these two species in all

495 phylogenies (Figures 4-7). Additionally, animals representing these genetic clades (estuarine

496 U.S. Atlantic/Gulf of Mexico and coastal Atlantic) were consistently differentiable based on

497 tentacle number (Figure 8A), oral arm length (Figure 8B) and holotrichous A-isorhiza

498 measurements (Figure 8C, 9). Two individuals (USNM 33457a and USNM 56703b) did not fit

499 the typical pattern for tentacle number (Figure 8A). However, both exhibited anomalous tentacle

500 morphologies (multiple tentacles emerging from within lappets instead of between lappets) and

501 had typical patterns for holotrichous A-isorhiza measurements (USNM 33457a: 27.59 x 20.98

502 um; USNM 56703b: $27.04 \times 21.75$ um; Figure 8C) and/or oral arm length (USNM 33457a: 4.54

503 times bell diameter; USNM 56703b: sample too degraded; Figure 8B).

504 It appears that Bigelow (1880) was correct that Chesapeake Bay Chrysaora that matured

505 at 24 tentacles represented a distinct taxon from Dactylometra quinquecirrha. Our data refute the

506 hypothesis that these individuals represent a growth stage toward the five-tentacled $C$.

507 quinquecirrha described from the coast (Mayer, 1910; Calder, 1972). However, an important

508 point is that it has been claimed that individuals only reach the "five-tentacled" stage after 130

509 mm (Agassiz \& Mayer 1898; Mayer 1910), when small tentacles emerge between the secondary

510 tentacles and the rhopalia (Mayer, 1910 Plate 64), termed Stage 5 in Calder (1972). In our data

511 set, only a single individual larger than $130 \mathrm{~mm}$ was encountered and collected from the 
512 estuarine Atlantic or Gulf of Mexico (Dauphin Island, AL) and it had exactly three tentacles per

513 octant (Figure 8A). However, it is possible that within the estuarine Atlantic and Gulf of

514 Mexico, these Chrysaora may develop small tertiary tentacles at very large sizes, though they

515 likely never develop fully, as was observed in some animals examined here. Furthermore, in one

516 case, Calder (1972) may have collected Chrysaora from an area (Broadkill River, DE) that

517 experiences both species, albeit at different times of the day, seemingly supporting the

518 hypothesis of development stages. The mouth of the Broadkill River experiences tidal inflows

519 capable of pulling coastal Chrysaora into the inlet during high tide and outflows capable of

520 pulling estuarine Chrysaora from the intercoastal waterway during low tide (K.M. Bayha, pers.

521 obs.). In any case, the growth of small tertiary tentacles in large estuarine Atlantic and Gulf of

522 Mexico Chrysaora, along with the dependence on a single morphological character (tentacle

523 number), likely led to the historical taxonomic uncertainties we are clarifying here.

524 Several lines of evidence support the U.S. Atlantic coastal Chrysaora group retaining the

525 species name C. quinquecirrha and the estuarine Atlantic/Gulf of Mexico group requiring a

526 different name. First, Pelagia quinquecirrha (=C. quinquecirrha) (Desor 1848) was described

527 from a coastal zone region (Nantucket Harbor, MA) as having 40 tentacles and our coastal

528 Atlantic animals were characterized by possessing 40 or more tentacles. Furthermore, one of our

529 sampling sites and a museum specimen were from coastal waters (Buzzard's Bay, MA) near the

530 C. quinquecirrha type locality. Assigning a species name to the U.S. Atlantic estuaries/Gulf of

531 Mexico group is more problematic, owing to inconsistencies in Papenfuss (1936). Papenfuss

532 (1936) compared two color morphs found within the Chesapeake Bay, a small, white morph (e.g.

533 Figure 3D) and a larger red striped morph (e.g. Figure 3E), which she assumed to be

534 Dactylometra (=Chrysaora) quinquecirrha. Papenfuss (1936) assigned the white morph to the 
535 new subspecies Dactylometra quinquecirrha var. chesapeakei, based on very small differences

536 in holotrichous a-isorhiza measurements, though without statistical support. However, for our

537 Norfolk (VA) samples, white (NF1-NF3) and red-striped (NF4-NF5) morphs occurred in the

538 same genetic clades for $16 S$ and $C O I$ (Figures 4-5) and we found no overall pattern of

539 differentiation in our holotrichous a-isorhiza measurements (Figure S2A). Furthermore, for

540 holotrichous A-isorhiza measurements, both morphs from Papenfuss (1936) are consistent with

541 our U.S. Atlantic estuary/Gulf of Mexico group (Figure 8C). In summary, evidence from

542 nematocyst measurements (Figure 8C), locality (Chesapeake Bay) and phylogenetic data (Figure

543 4-5) support the U.S. Atlantic estuarine/Gulf of Mexico group and both morphs from Papenfuss

544 (1936) as representing the same species. Even though Papenfuss (1936) may have been mistaken

545 in describing D. quinquecirrha var. chesapeakei, that name is taxonomically available based on

546 Article 45.6.4 of the International Code of Zoological Nomenclature (International Commission

547 on Zoological Nomenclature, 2015). As such, all animals from the U.S. Atlantic estuary/Gulf of

548 Mexico lineage should be assigned to the elevated species name Chrysaora chesapeakei

549 (Papenfuss, 1936). The placement of Gulf of Mexico medusae in C. chesapeakei differs from

550 Morandini \& Marques (2010), who placed them in the species C. lactea, based on similarities in

551 octant tentacle orientation (2-3-1-3-2). However, our genetic data clearly separate these animals

552 from the distantly related C. lactea (Figure 4-7) and the number of tentacles (approximately 3 )

553 and lack of tertiary tentacles in the Gulf of Mexico animals observed here and in Morandini and

554 Marques (2010) (USNM 49733 and USNM 53826) make accurate determination of tertiary

555 tentacle orientation problematic.

556 In addition to their taxonomic value, it is possible that some of the morphological

557 characters that delineate $C$. quinquecirrha and C. chesapeakei may be related to adaptations to 
558 different predominant prey items, especially for feeding on the ctenophore Mnemiopsis leidyi. In

559 general, M. leidyi, which is a major prey item for Chrysaora (Feigenbaum \& Kelly 1984),

560 exhibits an inshore, estuarine preference and a seasonal spread from estuarine to coastal waters

561 (Costello et al., 2012; Beulieu et al., 2013). As such, M. leidyi may be a more frequent prey item

562 for estuarine Atlantic Chrysaora than for coastal animals. Larger oral arms, as exhibited in $C$.

563 chesapeakei (Figure 8B), have been argued to be an adaptation for scyphozoans that feed on

564 gelatinous prey (Bayha and Dawson, 2010). In addition, the larger and more numerous A-

565 isorhiza nematocysts found in estuarine Chrysaora might be better suited to efficiently attaching

566 to and feeding on very soft-bodied organisms such as M. leidyi. Since different nematocyst types

567 are assumed to have different functions based on morphological and discharge characteristics

568 (Rifkin and Endean, 1983; Purcell, 1984; Heeger and Moller, 1987; Purcell and Mills, 1988;

569 Colin and Costello, 2007), it has been proposed that nematocyst diversity within an organism can

570 be correlated to dietary preferences, at least in a coarse sense (Purcell, 1984; Purcell and Mills,

571 1988; Carrette et al., 2002). In particular, isorhiza nematocysts, which typically serve to entangle

572 hard prey or penetrate soft tissue (Purcell and Mills, 1988; Colin and Costello, 2007), are likely

573 important for feeding on gelatinous prey, since they are the only types found in some jelly-

574 feeding medusae, such as hydrozoan narcomedusae (Purcell and Mills, 1988) and the

575 scyphozoan Drymonema larsoni (K.M. Bayha, pers. obs.). A-isorhizas are about twice as

576 numerous in C. chesapeakei as in C. quinquecirrha (16.5 $\pm 3.4 \%$ vs. $7.8 \pm 3.4 \%)$ and are

577 significantly larger (Figure 8C) in C. chesapeakei. It is possible that the more numerous A-

578 isorhizas, possessing longer tubules, could penetrate farther into the extremely soft-bodied $M$.

579 leidyi, resulting in greater capture efficiency. 
582 Chrysaora in the Caribbean

583 Chrysaora medusae collected from the Caribbean Sea are genetically very similar to

584 Chrysaora chesapeakei. Chrysaora in the Caribbean have historically been included in the

585 species C. lactea (Mayer 1910; Morandini \& Marques 2010), C. quinquecirrha (Perry \& Larson

586 2004) or Chrysaora sp. (Persad et al. 2003). Our Caribbean samples, limited only to Jamaica and

587 the Bocas del Toro region of Panama, appear to be two lineages (both found in JAM) slightly

588 diverged from each other (4.4-5.1\% for COI) and from C. chesapeakei $(6.2-7.7 \%$ for $C O I)$ from

589 the US east coast estuaries and the Gulf of Mexico. These animals cannot be assigned to $C$.

590 lactea (type locality=Rio de Janiero, Brazil), as was previously done by Mayer (1910) and

591 Morandini and Marques (2010), since these animals are distantly related to C. lactea for most

592 genetic regions examined (Figure 4-7). At present, it is unclear if the Caribbean forms represent

593 distinct or incipient species and further study of them from across the region is necessary. For the

594 time being, we advocate referring to Caribbean animals as Chrysaora c.f. chesapeakei ahead of a

595 formal systematic redescription based on genetic and careful morphological examination.

596

597 Chrysaora melanaster and C. pacifica

598 Our phylogenetic data confirm the morphological conclusions in Morandini \& Marques

599 (2010) that Japanese Chrysaora historically identified as C. melanaster, and labeled as such in

600 public aquaria worldwide for decades, are actually the distinct species C. pacifica. Kramp (1961)

601 synonymized the Pacific Chrysaora species C. melanaster (Brandt 1835) and the Japanese

602 jellyfish C. pacifica (Goette 1886) to C. melanaster. This identification convention made it into

603 jellyfish identification books (e.g. Wrobel and Mills, 1998) and subsequently Japanese 
604 Chrysaora labeled as C. melanaster became a mainstay in early jellyfish exhibits, such as the

605 Monterey Bay Aquarium (MBA), and then in aquaria throughout the world (W. Patry, pers.

606 comm.). Morandini \& Marques (2010) separated C. melanaster and C. pacifica on

607 morphological grounds (tentacle and lappet number) and deemed all aquarium specimens of

608 Japanese origin to be C. pacifica. Our data (Figure 4-5) confirm this, as aquarium-collected

609 jellyfish previously labeled C. melanaster (MBA) are distantly related to wild-caught $C$.

610 melanaster (BER) from its type locality (Bering Sea), but are nearly genetically similar

611 (sequence divergence: COI-0.5\%; 16S-0.6\%) to wild-caught Chrysaora collected from the

612 eastern Korean coast (KOR), where this jellyfish was recently redescribed as C. pacifica (Lee et

613 al. 2016) and Kyoto, Japan (KYO), both near the type locality of Nagasaki, Japan (Goette 1886).

614

615 Chrysaora africana/fulgida

616 Our phylogenies support the resurrection of Chrysaora species along the southwestern

617 coast of Africa. Three species of Chrysaora were previously identified from the southwestern

618 coast of Africa: Chrysaora hysoscella (Kramp 1955), C. fulgida (Reynaud 1830) and C. africana

619 (Vanhöffen 1902). However, Kramp (1961) deemed C. africana a variant of C. fulgida, and

620 Morandini \& Marques (2010) placed all of these sightings within the species C. fulgida. All

621 phylogenies indicate two distantly related species of Chrysaora from Namibian waters (Figures

622 4-7), with those appearing superficially similar to C. fulgida (brown striped) or to C. africana

623 (red tentacles) placed provisionally into these species. These designations are consistent with

624 upcoming re-descriptions of $C$. fulgida and C. africana of S. Neethling (unpublished data) based

625 on morphological and genetic analyses. Chrysaora has increased over recent years in this area, 
626 with concomitant ecological perturbations (Lynam et al. 2006; Flynn et al. 2012; Roux et al.

627 2013), underscoring the importance of correct species identification.

628

$629 \underline{\text { Mawia benovici }}$

630 In addition to revealing higher level phylogenetic relationships, our data add to our

631 knowledge regarding the distribution of $M$. benovici, indicating a possible source region for the 632 introduced species. Piraino et al. (2014) hypothesized that Mawia benovici (then Pelagia

633 benovici), likely arrived into the Adriatic Sea via ballast water. Our data indicate that two small 634 pelagiid jellyfishes collected from the beach near Dakar, Senegal are M. benovici based on COI 635 and $28 S$ phylogenies (Figure 4, 6) (there are no published $16 S$ sequences for M. benovici). While 636 this is not definitive evidence that Mediterranean $M$. benovici populations originated from the 637 western coast of Africa, it raises the possibility. While many West African species have arrived 638 in the Mediterranean through the Strait of Gibraltar or occasionally inhabit the western 639 Mediterranean (Gofas \& Zenetos 2003; Antit, Gofas \& Azzouna 2010), there are examples of 640 animals introduced via shipping or fishing practices from West Africa to the Mediterranean (Ben 641 Souissi et al. 2004; Antit, Gofas \& Azzouna 2010; Luque et al. 2012; Zenetos et al. 2012). If M.

642 benovici did originate from the western coast of Africa, it is more likely that it was a result of 643 shipping or fishing practices, since there are no records of $M$. benovici between Gibraltar and the 644 Adriatic Sea to our knowledge.

645 


\section{SYSTEMATICS}

647 Chrysaora quinquecirrha Desor, 1848

648 Figure 3A, 3B, 4-9, S1-S2.

649

650

Pelagia quinquecirrha-Desor (1848): p. 76 (original description - Nantucket Sound, MA).

651

Dactylometra quinquecirrha: Agassiz (1862): 126, 166 [tentacle number]. Agassiz (1865):

652

48, 49 [tentacle number; Naushon, MA]. Fewkes (1881): 173, Pl. VIII Fig. 14 [tentacle number, 653 drawing]. Brooks (1882): 137 [tentacles, drawing in Mayer, 1910; southern variety outside

654

Beaufort Inlet]. Agassiz \& Mayer (1898): 1-6, Plate I [tentacles, oral arms, drawing]. Fish

655

(1925): 128, 130 [Vineyard Sound, MA; Nonamesset, MA; Lackeys Bay, MA]. Mayer (1910):

656 585-588, Pl. 64A [tentacles, drawing].

657

Chrysaora quinquecirrha: Kramp (1961): 327-328 [description fits both $C$.

658

quinquecirrha and C. chesapeakei]. Calder (1972): 40-43, Figures 5-6 [mouth of Broadkill

659

River, DE]. Kraeuter \& Setzler (1975): 69, Figures 1-2 [offshore samples, Sea Buoy]. Calder

660

(2009): 24-28 [offshore animals collected on continental shelf possibly C. quinquecirrha].

661

662 Diagnosis: Living medusae up to $40 \mathrm{~cm}$ (observed 59.0 - $176.0 \mathrm{~mm}$ ) (Figures 3A, 3B); tentacles

663 typically 40 or more; $5.28 \pm 0.45(95 \% \mathrm{CI})$ tentacles/octant on average (Table 3; Figure $8 \mathrm{~A})$;

664 primary tentacle central, secondary and tertiary tentacles laterally (3-2-1-2-3); lappets rounded

665 typically 48 or more; $6.26 \pm 0.46$ lappets/octant on average; rhopalar lappets slightly larger than

666 tentacular lappets; can be differentiated from C. chesapeakei based on 1) smaller size of

667 holotrichous A-isorhiza nematocysts: average: $20.25[ \pm 0.38] \mu \mathrm{m} \times 11.27[ \pm 0.37] \mu \mathrm{m}$ (Table 3; 
668 Figure $8 \mathrm{C}$ ); 2) larger tentacle number (more than 5 per octant) and 3 ) typically shorter maximum 669 oral arm length (average: $1.24 \pm 0.27$ time bell diameter).

670

671 Material Examined: USNM 24496 ( $n=1$; Buzzard's Bay, MA), USNM 53860 ( $n=1$; Assateague 672 Island, VA), USNM 53861 ( $n=1$; Assateague Island, VA), USNM 54511 ( $n=2$; Cape Henlopen, 673 DE), USNM 56702 ( $n=1$; Cape Henlopen, DE), USNM 1454776 - USNM 1454778, KMBCDE2, $674 \mathrm{KMBCDE} 4(n=5$; Cape Henlopen, DE).

675

676 Description of holotype: No holotype located, no neotype designated.

677

678 Description of specimens: Bell diameter up to approximately $40 \mathrm{~cm}$ (observed 59.0-176.0 mm), 679 almost hemispherical. Exumbrella finely granulated with small, inconspicuous marks (papillae); 680 exumbrellar color varies from entirely transparent white to white with inconspicuous radial 681 markings. Tentacle number approximately 5 tentacles per octant, but can be more (average 5.28 $682 \pm 0.48$ ) (Table 3; Figure 8A); primary tentacle central, secondary and tertiary tentacles laterally $683(3-2-1-2-3)$ with additional tentacles originating toward the rhopalia; lappets rounded typically 68448 or more (average $6.26 \pm 0.46$ per octant); Tentacle clefts of varied depth with primary clefts 685 deeper than secondary clefts. Radial and ring musculature not obvious. Brachial disc circular. 686 Pillars evident. No quadralinga. Subgenital ostia rounded, approximately 1/8 of bell diameter.

687 Oral arms v-shaped with frills emanating from tube-like structure; straight without spiral; curved, 688 frilled edges taper toward distal end of oral arms. Oral arms short, approximately the same length 689 as bell diameter (average $1.24 \pm 0.27$ times bell diameter). Oral arms typically transparent white. 6904 semi-circular gonads, white, pinkish or slightly orange, well developed within pouch outlining 
691 gastric filaments. 16 stomach pouches bounded by 16 septae. Septae bent at 45 -degree angle

692 distally towards the rhopalia terminating near tentacle in rhopalar lappet, resulting in tentacular

693 pouches being somewhat larger than rhopalar pouches distally.

694 Cnidome (tentacle). Average Dimensions (Length $\pm 95 \%$ CI x Width $\pm 95 \%$ CI)

$695 \quad$ Holotrichous A-isorhizas: $20.15 \pm 0.33 \times 11.13 \pm 0.24 \mu \mathrm{m}$;

$696 \quad$ Holotrichous a-isorhizas: $8.27 \pm 0.49 \times 4.22 \pm 0.07 \mu \mathrm{m}$;

697

Holotrichous O-isorhizas: $21.63 \pm 0.39 \times 18.91 \pm 0.78 \mu \mathrm{m}$;

698

Heterotrichous microbasic rhopaloids: $13.58 \pm 0.19 \times 8.09 \pm 0.09 \mu \mathrm{m}$;

699

700

Type Locality: Nantucket Bay, Nantucket Island, Massachusetts, East Coast of USA.

701

702 Habitat: Medusae are found in open coastal waters on the US Atlantic coast.

703

704 Distribution: Western North Atlantic, east coast of the USA south of Cape Cod in coastal 705 Atlantic waters at least as far south as Georgia/northern Florida.

706

707 DNA sequence: Mitochondrial $C O I$ and $16 S$ and Nuclear $28 S$ sequence data are available in

708 NCBI GenBank under accession numbers MF141552-MF141556, MF141608, MF141613-

709

MF141614, MF141628, MF141635, MF141642-MF141646, MF141688-MF141689, MF141697.

710

711 Phylogeny: C. quinquecirrha and C. chesapeakei sequences form reciprocally monophyletic

712 groups for 16S, COI, $28 S$ and combined analyses (Figures 4-7). Minimum sequence divergences

713 between $C$. quinquecirrha and $C$. chesapeakei clades (COI: 12.1\%, 16S: 8.4\%, 28S: 2.4\%) were 
714 much larger than the maximum within clades for C. quinquecirrha (COI: $0.2 \%, 16 S: 0.1 \%, 28 S$ :

$7150.0 \%$ ) or C. chesapeakei (COI: 0.7\%, 16S: 0.6\%, 28S: 0.4\%). C. quinquecirrha sequences did

716 not form monophyletic groups with any other species (Figures 4-7).

717

718 Biological Data: Although the name Chrysaora quinquecirrha applies to the US coastal Atlantic

719 species, almost no ecological studies have been done on the coastal species, apart from (Kraeuter

720 \& Setzler 1975), which found the largest C. quinquecirrha individual was found in a coastal area

721 about $90 \mathrm{~km}$ offshore in full seawater (Salinity $>30$ ).

722

723 Notes: Since this species retains the scientific name C. quinquecirrha, we advocate it retaining

724 the common name "U.S. Atlantic sea nettle", since it is also a coastal and open ocean species.

725

726 Chrysaora chesapeakei Papenfuss, 1936

727 Figures 3C, 3D, 3E, 4-9, S1-S2

728

729

Dactylometra quinquecirrha: (Bigelow 1880): 66 [white colored morph, Chesapeake Bay].

730 Brooks (1882): 137 [Chesapeake Bay-USA]. (Agassiz \& Mayer 1898): 48-49 [upper

731 Narragansett Bay (RI)]. Mayer (1910): 585-588, P1.63-64 [24 tentacle morph, white, red/brown

732 striped morph, Tampa Bay (FL), Hampton Roads (VA), St. Mary’s (MD)]. Papenfuss (1936):

733 14-17, Figures 7, 11, 16, 20 [lower Chesapeake Bay; red striped morph based on A-isorhiza

734 measurements]. Littleford \& Truitt (1937): 91 [Chesapeake Bay]. Littleford (1939): 368-381,

735 Pls. I-III [Chesapeake Bay]. Hedgepeth (1954): 277-278 [Tampa Bay (FL), Gulf of Mexico].

736 Dactylometra quinquecirrha var. chesapeakei: Papenfuss (1936): 14-17, Figures 12, 21 
737 [Chesapeake Bay; white colored morph based on A-isorhiza measurements].

738 Chrysaora quinquecirrha: Kramp (1961): 327-328 [parts of description covers both C.

739 quinquecirrha and C. chesapeakei]. Rice \& Powell (1970): 180-186 [Chesapeake Bay]. Burke

740 (1976): 20, 22-28 [Mississippi Sound, Gulf of Mexico]. Calder (1971): 270-274 [Gloucester

741 Point (VA) - Chesapeake Bay]. Calder (1972): 40-43, Figures 1-4 [Chesapeake Bay, Pamlico

742 Sound, Gulf of Mexico]. Loeb (1972): 279-291 [Chesapeake Bay]. Loeb (1973): 144-147

743 [Chesapeake Bay]. Loeb \& Blanquet (1973): 150-157 [Chesapeake Bay]. Calder (1974b): 326-

744333 [Chesapeake Bay]. Loeb (1974): 423-432 [Chesapeake Bay]. Blanquet \& Wetzel (1975):

745 181-192 [Chesapeake Bay]. Cargo (1975): 145-154 [Chesapeake Bay]. Kraeuter \& Setzler

746 (1975): 69, Figures 1-2 [Doboy Sound (GA)]. Loeb \& Gordon (1975): 37-41 [Chesapeake Bay].

747 Lin \& Zubkoff (1976): 37-41 [Chesapeake Bay]. Calder (1977): 13-19 [Gloucester Point, MD -

748 Chesapeake Bay]. Clifford \& Cargo (1978): 58-60 [Patuxent River, MD - Chesapeake Bay].

749 Cargo (1979): 279-286 [Chesapeake Bay]. Cargo \& Rabenold (1980): 20-26 [Patuxent River

750 (MD)]. Hutton et al. (1986): 154-155 [Chesapeake Bay]. Cargo \& King (1990): 486-491

751 [Chesapeake Bay]. Purcell et al. (1991): 103-111 [Choptank River, MD - Chesapeake Bay].

752 Nemazie, Purcell \& Glibert (1993): 451-458 [Chesapeake Bay]. Purcell, White \& Roman (1994):

753 263-278 [Chesapeake Bay]. Burnett et al. (1996): 1377-1383 [Chesapeake Bay]; Houck et al.

754 (1996): 771-778 [St. Margaret's, MD - Chesapeake Bay]. Olesen, Purcell \& Stoecker (1996):

755 149-158 [Broad Creek (MD) - Chesapeake Bay]. Ford et al. (1997): 355-361 (Choptank River

756 (MD) - Chesapeake Bay]. Kreps, Purcell \& Heidelberg (1997): 441-446 [Choptank River (MD)

757 - Chesapeake Bay]. Wright \& Purcell (1997): 332-338 [Patuxent River (MD) - Chesapeake

758 Bay]. Suchman \& Sullivan (1998): 237-244 [Green Hill Pond (RI)]. Purcell, Malej \& Benović

759 (1999): 241-263 [Chesapeake Bay]. Purcell et al. (1999): 187-196 [Choptank River (MD) - 
760 Chesapeake Bay]. Bloom, Radwan \& Burnett (2001): 75-90 [St. Mary's (MD) - Chesapeake

761 Bay]. Condon, Decker \& Purcell (2001): 89-95 [Choptank River (MD) - Chesapeake Bay].

762 Graham (2001): 97-111 [Gulf of Mexico]. Johnson, Perry \& Burke (2001): 213-221 [Gulf of

763 Mexico]. Matanoski, Hood \& Purcell (2001): 191-200 [Choptank River (MD) - Chesapeake

764 Bay]. Segura-Puertas, Suárez-Morales \& Celis (2003): 9 [Gulf of Mexico]. Ishikawa et al.

765 (2004): 895-899 [Gibson Island (MD) - Chesapeake Bay]. Grove \& Breitburg (2005): 185-198

766 [Patuxent River (MD) - Chesapeake Bay]. Purcell \& Decker (2005): 376-385 [Chesapeake

767 Bay]. Thuesen et al. (2005): 2475-2482 [Chesapeake Bay]. Breitburg \& Fulford (2006): 776-784

768 [Solomon's Island [MD] - Chesapeake Bay]. Kimmel, Roman \& Zhang (2006): 131-141 [mid to

769 upper Chesapeake Bay]. Decker et al. (2007): 99-113 [Chesapeake Bay]. Condon \& Steinberg

770 (2008): 153-168 [York River (VA) - Chesapeake Bay]. Calder (2009): 24-28 [estuarine

771 animals]. Matanoski \& Hood (2006): 595-608 [Choptank River (MD) - Chesapeake Bay].

772 Purcell (2007): 184, 190-192 [Chesapeake Bay]. Purcell (2009): 23-50 [Chesapeake Bay]. Duffy, 773 Epifanio \& Fuiman (1997): 123-131 [Port Aransas (TX) - Gulf of Mexico]. Bayha \& Graham

774 (2009): 217-228 [Rhode Island, New Jersey, Chesapeake Bay, Georgia, Alabama]. Sexton et al.

775 (2010): 125-133 [Choptank River (MD) - Chesapeake Bay]. Birsa, Verity \& Lee (2010): 426-

776430 [Skidaway River (GA), Wassow Sound (GA)]. Condon, Steinberg \& Bronk (2010): 153-170

777 [York River (VA) - Chesapeake Bay]. Condon et al. (2011): 10225-10230 [Chesapeake Bay].

778 Frost et al. (2012): 247-256 [Steinhatchee River (FL) - Gulf of Mexico]. Duarte et al. (2012):

779 91-97 [St. Leonard's (MD) - Chesapeake Bay]. Kimmel, Boynton \& Roman (2012): 76-85

780 [Solomon's Island (MD) - Chesapeake Bay]. Sexton (2012): 1-153 [Chesapeake Bay]. Brown et

781 al. (2013): 113-125 [Chesapeake Bay]. Robinson \& Graham (2013): 235-253 [Gulf of Mexico].

782 Breitburg \& Burrell (2014): 183-200 [Patuxent River (MD) - Chesapeake Bay]. Kaneshiro- 
783 Pineiro \& Kimmel (2015): 1965-1975 [Pamlico Sound (NC). Meredith, Gaynor \& Bologna

784 (2016): 6248-6266 [Barnegat Bay (NJ)]. Tay \& Hood (2017): 227-242 [Choptank River (MD),

785 Chesapeake Bay].

786

787 Diagnosis: Living medusae up to $20 \mathrm{~cm}$ (observed 17.0-175.0 mm; average: 63.0

$788 \mathrm{~mm}$ ); Tentacles typically number 24 or 3 per octant (average $3.07 \pm 0.07$ ); primary tentacle central

789 and secondary tentacles lateral (2-1-2); rarely, additional tentacles arise lateral to secondary

790 tentacles (3-2-1-2-3) and are typically undeveloped; marginal lappets rounded and typically 32 or

7914 per octant (average $4.08 \pm 0.06$ ); rhopalar lappets are typically about the same size as

792 tentacular lappets; can be differentiated from C. quinquecirrha based on 1) larger size of

793 holotrichous A-isorhiza nematocysts: $26.21[ \pm 0.50] \mu \mathrm{m} \times 19.74[ \pm 0.55] \mu \mathrm{m} ; 2)$ smaller tentacle

794 number ( $\sim 3$ tentacles per octant); and 3) larger maximum oral arm length (average: $3.00 \pm 0.39$

795 times bell diameter).

796

797 Material Examined. Neotype: - USNM 1454948 - (Gloucester Point, MD -

798 Chesapeake Bay). Other comparative specimens: USNM 57925 ( $n=9$; Orange Inlet, NC), USNM

79956758 ( $n=5$; Charlestown Pond, RI), USNM 33456 ( $n=4$; Plum Point, MD), USNM 49733 ( $n=1$;

800 Alligator Harbor, FL), USNM 53826 ( $n=2$; Timbalier Bay, LA), USNM 56703 ( $n=2$;

801 Chesapeake Bay 37.23 N 76.04 W), USNM 56704 ( $n=4$; Chesapeake Bay 37.23 N 76.04 W),

802 USNM 53870 ( $n=3$; Beaufort, NC), USNM 53828 ( $n=2$; Drum Point, MD), USNM 33458 ( $n=3$;

803 Plum Point, MD), USNM 33457 (n=4; Plum Point, MD), USNM 55621 ( $n=6$; near Chesapeake

804 Beach, MD), USNM 53867 ( $n=1$; Arundel on the Bay, MD), USNM 54404 ( $n=1$; Chesapeake

805 Bay 37.23 N 76.04 W), USNM 33121 ( $n=6$; Arundel on the Bay, MD), USNM 42155 ( $n=2$; 
806 Louisiana, Gulf of Mexico), USNM 54372 ( $n=1$; Lake Pontchartrain, LA); USNM 1454941 -

807 USNM 1454943, KMBCSC1, KMBCSC4-KMBCSC5, KMBCSC7 ( $n=7$; Charleston Harbor,

808 SC), USNM 1454944 - USNM 1454951, KMBGVA1, KMBGVA5, KMBGVA7, KMBGVA10

809 ( $n=12$; Gloucester Point, VA), KMBCRI1-KMBCRI14 ( $n=14$; Charlestown Pond, RI),

810 KMBRDE1-KMBRDE16 ( $n=16$; Rehoboth Bay, DE), USNM 1454956, KMBDIA2-KMBDIA3

811 ( $n=3$; Dauphin Island, AL).

812

813 Description of neotype specimen: USNM 1454948. Bell diameter $110.4 \mathrm{~mm}$, almost

814 hemispherical. Exumbrella white/clear with granulated surface of small white marks. 8 rhopalia.

815 No ocelli. Deep rhopalar clefts; deep sensory pits. Marginal lappets rounded, 32 total or 4 per

816 octant made up of two rhopalar lappets and two tentacular lappets. Lappet size barely

817 heterogeneous, with rhopalar lappets about the same width as tentacular lappets but longer.

818 Tentacle number 24 or 3 per octant, with primary tentacle surrounded by two secondary tentacles

819 (2-1-2), primary tentacle longer than secondary tentacles, up to 3-4 times bell diameter.

820 Tentacles are white, slightly pinkish. Tentacle clefts of varied depth with primary clefts deeper

821 than secondary clefts. Radial and ring musculature not obvious. Brachial disc circular. Pillars

822 evident. No quadralinga. Subgenital ostia rounded, approximately 1/10 of bell diameter. Oral

823 arms white, v-shaped with frills emanating from tube-like structure. Oral arms straight without

824 spiral curved, frilled edges taper toward distal end of oral arms. Orals arms long, approximately

8255 (4.98) times bell diameter. 4 semi-circular gonads, white (a bit orange), well developed within

826 pouch outlining gastric filaments. 16 stomach pouches bounded by 16 septae. Septae bent at $45-$

827 degree angle distally towards the rhopalia terminating near tentacle in rhopalar lappet, resulting

828 in tentacular pouches being somewhat larger than rhopalar pouches distally. 
829 Cnidome (tentacle): Average dimensions (Length $\pm 95 \%$ CI x Width $\pm 95 \%$ CI)

$830 \quad$ Holotrichous A-isorhizas: $25.66 \pm 0.83 \times 19.16 \pm 0.54 \mu \mathrm{m}$;

$831 \quad$ Holotrichous a-isorhizas $7.77 \pm 0.20 \times 4.17 \pm 0.10 \mu \mathrm{m}$;

$832 \quad$ Holotrichous O-isorhizas $22.02 \pm 0.30 \times 19.95 \pm 0.24 \mu \mathrm{m}$;

833 Heterotrichous microbasic rhopaloids $12.35 \pm 0.47 \mu \mathrm{m} \times 8.55 \pm 0.55 \mu \mathrm{m}$.

834

835 Description of other specimens: Bell diameter up to approximately $20 \mathrm{~cm}$ (observed 17.0-

$836175.0 \mathrm{~mm}$ ), almost hemispherical but flattened in small individuals. Exumbrellar finely

837 granulated with small, inconspicuous marks (papillae); exumbrellar color varies considerably,

838 varying from all white to a completely brown or red colored bell, to a bell with radial lines of

$839 \mathrm{red} /$ brown with a spot in the center of the bell. Radial lines may be relatively inconspicuous

840 without a noticeable spot in the center. Tentacles typically number 24 or 3 per octant (average

$8413.07 \pm 0.07)$, with primary tentacle surrounded by two secondary tentacles $(2-1-2)$, primary

842 tentacle longer than secondary tentacles, up to 3-4 times bell diameter. In some rare cases, small

843 tentacles may occur laterally to secondary tentacle, occurring between the secondary tentacle and

844 rhopalium. In almost all cases, this tentacle is similar in size to or smaller than the lappets

845 surrounding it. In very rare cases (twice observed), about 5 or more tentacles per octant have

846 been seen, though these medusae had aberrant tentacle patterns overall (e.g. more than one

847 tentacle emerging from same spot, tentacles emerging below lappet). Tentacles are white,

848 slightly pinkish. Marginal lappets rounded and typically 32 or 4 per octant (average $4.08 \pm 0.06$ ).

849 Tentacle clefts of varied depth with primary clefts deeper than secondary clefts, which are deeper

850 than rare tertiary clefts. Radial and ring musculature not obvious. Brachial disc circular. Pillars

851 evident. No quadralinga. Subgenital ostia rounded, approximately 1/10 of bell diameter. Oral 
852 arms v-shaped with frills emanating from tube-like structure; straight without spiral; curved,

853 frilled edges taper toward proximal end of oral arms. Oral arms long, approximately 3 times bell

854 diameter on average (as much as 5.6 times bell diameter). Oral arms vary in color, from

855 transparent white, to red or brown colored tubule surrounded by pinkish frilled edges. 4 semi-

856 circular gonads, white, pinkish or slightly orange, well developed within pouch outlining gastric

857 filaments. 16 stomach pouches bounded by 16 septae. Septae bent at 45 -degree angle distally

858 towards the rhopalia terminating near tentacle in rhopalar lappet, resulting in tentacular pouches

859 being somewhat larger than rhopalar pouches distally.

860 Cnidome (tentacle). Average Dimensions (Length $\pm 95 \%$ CI x Width $\pm 95 \%$ CI)

$861 \quad$ Holotrichous A-isorhizas: $26.21 \pm 0.50 \times 19.74 \pm 0.55 \mu \mathrm{m}$;

$862 \quad$ Holotrichous a-isorhizas: $7.88 \pm 0.13 \times 4.29 \pm 0.07 \mu \mathrm{m}$;

$863 \quad$ Holotrichous O-isorhizas: $23.10 \pm 0.43 \times 20.75 \pm 0.62 \mu \mathrm{m}$;

$864 \quad$ Heterotrichous microbasic rhopaloids: $12.73 \pm 0.22 \times 8.29 \pm 0.13 \mu \mathrm{m}$;

865

866 Type Locality: Gloucester Point (VA), Chesapeake Bay, east coast of USA.

867

868 Habitat: Medusae are found in estuarine waters on the US Atlantic coast and estuarine and

869 nearshore waters of the Gulf of Mexico.

870

871 Distribution: Western North Atlantic, east coast of the USA south of New England to

872 the Gulf of Mexico, restricted to estuarine waters on the Atlantic coast, known to exist outside of 873 estuaries in the Gulf of Mexico.

874 
875 Notes: Since $C$. chesapeakei is commonly found in estuarine waters, we advocate the common

876 name "U.S. Atlantic bay nettle" to distinguish it from the "U.S. Atlantic sea nettle" $(C$.

877 quinquecirrha). The specific name chesapeakei originates from Dactylometra quinquecirrha var. 878 chesapeakei of Papenfuss (1936). For Papenfuss (1936), it is clear that: 1) the manuscript likely 879 compared nematocyst measurements between two color morphs of C. chesapeakei and did not 880 include C. quinquecirrha s. str. (see Discussion; Figure 8C); and 2) differences invoked for 881 holotrichous a-isorhizas are in question, since the nematocysts are small ( $\sim 1.5 \mathrm{um})$, making 882 identifying differences difficult even with more precise, modern instruments, and the data are not 883 accompanied by any statistics or measurement error. Regardless, based on Article 35.6.4 of the 884 International Code of Zoological Nomenclature $4^{\text {th }}$ Edition (ICZN 1999), the specific name 885 chesapeakei has taxonomic priority and C. chesapeakei applies to the Chesapeake Bay animals, 886 as well as estuarine Atlantic and Gulf of Mexico animals that are genetically similar, and have 887 similar macromorphological and cnidome characteristics (Figures 4-9). Papenfuss (1936) did not 888 designate a type specimen for Dactylometra (=Chrysaora) quinquecirrha var. chesapeakei. We 889 designate the specimen USNM 1454948 as a neotype specimen so that a physical specimen, 890 along with preserved tissue for genetic analysis, will be available to objectively define $C$.

891 chesapeakei [see Article 75 of the International Code for Zoological Nomenclature (ICZN 892 1999)], which will be necessary given the close genetic relationship between this species and 893 specimens from the Caribbean (see below). Our neotype specimen originates from Gloucester 894 Bay (VA), within the Chesapeake Bay, where Papenfuss (1936) hypothesized Dactylometra 895 (=Chrysaora) quinquecirrha var. chesapeakei to be confined. 896 
897 DNA sequence: Mitochondrial $C O I$ and $16 S$ and Nuclear $28 S$ sequence data are available in

898 GenBank under accession numbers MF141564-MF141587, MF141615-MF141617, MF141637-

899 MF141639, MF141649-MF141669, MF141699-MF141718, MF167556-MF167568.

900

901 Phylogeny: C. chesapeakei and C. quinquecirrha sequences form reciprocally monophyletic

902 groups for $16 S, C O I, 28 S$ and combined analyses (Figures 4-7). Minimum sequence divergences

903 between $C$. chesapeakei and $C$. quinquecirrha clades (COI: 12.1\%, 16S: 8.4\%, 28S: 2.5\%) were

904 much larger than the maximum within clades for C. quinquecirrha (COI: $0.3 \%, 16 S: 0.1 \%, 28 S$ :

$9050.0 \%$ ) or C. chesapeakei (COI: 2.2\%, 16S: 1.9\%, 28S: 0.7\%). C. chesapeakei sequences do not

906 form monophyletic groups with any other species (Figures 4-7).

907

908 ACKONWLEDGEMENTS

909 We are grateful to John McDonald for his guidance during the developmental phases of the

910 project and his vital manuscript edits. We acknowledge the following for collecting samples or

911 aiding sample collection: Emmanuelle Buecher, Luciano Chiaverano, Mike Davis, Elif Demir,

912 Chris Doller, Tom Doyle, Lisa-Ann Gershwin, Mark Gibbons, Monty Graham, Bill Hall,

913 Shannon Howard, Lucy Keith-Diagne, Monica Martinussen, George Matsumoto, Hermes

914 Mianzan, Wyatt Patry, Jennifer Purcell, Steve Spina, Barbara Sullivan, the crew and personnel of 915 the R/V Cape Henlopen, The Port Royal Marine Laboratory, the Monterey Bay Aquarium, the

916 Aquarium of the Americas and the South Carolina Aquarium. Some molecular and microscopic

917 work was performed using resources of the Laboratory of Analytical Biology at the Smithsonian

918 National Museum of Natural History and some molecular work was performed in the labs of Dr.

919 William Graham and Dr. Michael Dawson. We acknowledge Scott Whittaker for his 
920 micropscopic assistance. We are thankful to Phillipe Bouchet, Dale Calder and Steve Cairns for

921 their critical nomenclatural advice.

922 
923 FIGURES

924

925 Figure 1: World map showing collecting sites of animals sequenced for this study. Final

926 species designations are employed. All aquarium samples (C. achlyos, C. chinensis, C. colorata,

927 C. fuscescens and C. pacifica) originated from cultures at the Monterey Bay Aquarium, although

928 some were obtained from the Aquarium of the Americas. Their locations on the map are based

929 on original collection locations for the aquarium cultures (W. Patry, pers. comm.).

930

931 Figure 2: Collection locations of Chrysaora quinquecirrha s.l. medusae used in this study.

932 Abbreviations all refer to Tables 1 and S1. Figures 2 (A-C) are enlargements of rectangular inset

933 regions. The star at Nantucket harbor indicates the type locality of C. quinquecirrha (Desor,

934 1848). Diamonds represent important museum collection sites (Table S1). Site RI is within the

935 enclosed Charlestown Pond, RI (41.364.765 N, 71.628865 W). Site NJ is at Ocean Gate Yacht

936 Club (39.930490 N, 74.140448 W) on Toms River, inside Barnegat Bay. Site RB was collected

937 from inside Rehoboth Bay, DE (38.688091 N, 75.077114 W). All Chesapeake Bay samples (NF

938 and Gloucester Point, VA) were taken from well within the Chesapeake Bay. Site PAM was

939 collected from Englehard, NC (35.509102 N, 75.989712 W), well within Pamlico Sound. CST

940 was taken from within Charleston Harbor (32.786995 N, 79.909297 W). Site GA was taken from

941 Fancy Bluff Creek, upstream from Saint Simons Sound, GA (31.166291 N, 81.416032 W).

942 Sample sites with individuals finally designated as C. quinquecirrha are in white and those with

943 individuals finally designated as C. chesapeakei in black.

944

945 Figure 3: Various morphs of C. quinquecirrha s.l. A) Offshore South Carolina (OSC); B)

946 Sample taken from offshore Georgia; C) Englehard, NC (PAM); D) White Chesapeake Bay color 
947 morph (Broome's Island, MD - Patuxent River); E) Red-striped Chesapeake Bay color morph

948 (Solomons, MD - Patuxent River). Note that medusae from A-B have 5 tentacles per octant,

949 while C-E have three tentacles per octant. Medusae in 3A and 3C were included in this study's

950 phylogenetic analyses. (3A: OSC1; 3C: PAM1). A-B represent individuals finally designated

951 as C. quinquecirrha; C-E represent individuals finally designated as C. chesapeakei. Photo

952 Credits: 3A) Shannon Howard; 3B) Greg McFall-NOAA; 3E) Robert Condon.

953

954 Figure 4: Pelagiidae COI Phylogeny. Bayesian Inference (BI) COI tree reconstructed from

955 CLUSTAL alignment using Mr. Bayes v3.2.4 and applying the GTR $+\mathrm{I}+\mathrm{G}$ model of sequence

956 evolution. Numbers adjacent to branches show bootstrap support if $\geq 0.70$ (presented as a

957 percentage), followed by bootstrap support from maximum likelihood (ML) analysis if $\geq 50 \%$.

958 ML phylogeny was reconstructed using PhyML v3.0 (Guindon et al. 2010) applying the

959 TPM2uf $+\mathrm{I}+\mathrm{G}$ model of sequence evolution (-lnl 5451.81154) as determined by jMODELTEST

960 v2.1.7 (Darriba et al. 2012). Abbreviations refer to Tables 1-2. Specific identification to the right

961 of the tree indicates final species designations. Clades colored in gray were originally identified

962 as C. quinquecirrha. Norfolk (VA) individuals NF1-NF3 were identified as white Chesapeake

963 Bay color morph and individuals NF4-NF5 as red-striped Chesapeake Bay color morph (Figure

964 3D-E).

965

966 Figure 5: Pelagiidae 16S Phylogeny. Bayesian Inference (BI) $16 S$ tree reconstructed from

967 MAFFT alignment using Mr. Bayes v3.2.4 and applying the GTR $+\mathrm{I}+\mathrm{G}$ model of sequence

968 evolution. Numbers adjacent to branches show bootstrap support if $\geq 0.70$ (presented as a

969 percentage), followed by bootstrap support from maximum likelihood (ML) analysis if $\geq 50 \%$. 
970 ML phylogeny was reconstructed using PhyML v3.0 (Guindon et al. 2010) applying the

971 TIM2+I+G model of sequence evolution (-lnl 3641.97519) as determined by jMODELTEST

972 v2.1.7 (Darriba et al. 2012). Gray arrows indicate nodes that are alternated in the ML tree.

973 Abbreviations refer to Tables 1-2. Specific identification to the right of the tree indicates final

974 species designations. Clades colored in gray were originally identified as C. quinquecirrha s.1.

975 Norfolk (VA) individuals NF1-NF3 were identified as white morph and individuals NF4-NF5 as 976 red-striped bell morphs (Figure 3D-E).

977

978 Figure 6: Pelagiidae 28S Phylogeny. Bayesian Inference (BI) $28 S$ tree reconstructed from 979 MAFFT alignment using Mr. Bayes v3.2.4 and applying the GTR $+\mathrm{I}+\mathrm{G}$ model of sequence 980 evolution. Numbers adjacent to branches show bootstrap support if $\geq 0.70$ (presented as a 981 percentage), followed by bootstrap support from maximum likelihood (ML) analysis if $\geq 50 \%$.

982 ML phylogeny was reconstructed using PhyML v3.0 (Guindon et al. 2010) applying the 983 TrNef $+\mathrm{I}+\mathrm{G}$ model of sequence evolution (-lnl 3817.02691) as determined by $\mathrm{jMODELTEST}$ 984 v2.1.7 (Darriba et al. 2012). Specific identification to the right of the tree indicates final species 985 designations. Clades colored in gray were originally identified as C. quinquecirrha. 986

987 Figure 7: Pelagiidae Combined Phylogeny. Bayesian Inference (BI) tree of the combined dataset 988 applying the GTR $+\mathrm{I}+\mathrm{G}$ model of sequence evolution. Numbers adjacent to branches show 989 bootstrap support if $\geq 0.70$ (presented as a percentage), followed by bootstrap support from 990 maximum likelihood (ML) analysis if $\geq 50 \%$. ML phylogeny was reconstructed using PhyML 991 v3.0 (Guindon et al. 2010) applying the GTR $+\mathrm{I}+\mathrm{G}$ model of sequence evolution (-lnl 992 11924.23655) as determined by jMODELTEST v2.1.7 (Darriba et al. 2012). Specific 
993 identification to the right of the tree indicates final species designations. Clades colored in gray

994 were originally identified as C. quinquecirrha.

995

996 Figure 8: Morphological evidence separating C. quinquecirrha and C. chesapeakei. A) Tentacle

997 counts. Graph represents tentacles per octant against bell diameter $(\mathrm{mm})$ for field collected and

998 museum specimens. Squares represent animals taken from estuarine Atlantic and Gulf of Mexico

999 regions (C. chesapeakei), while circles represent animals taken from coastal Atlantic regions $(C$.

1000 quinquecirrha). All animals with $16 S$ sequences matching the C. chesapeakei clade appear in

1001 red, while those whose sequences matched the C. quinquecirrha clade appear in blue. B)

1002 Maximum oral arm measurements. Graph represents maximum oral arm length against bell

1003 diameter $(\mathrm{mm})$ for field-collected and museum specimens. Squares represent animals taken from

1004 U.S. Atlantic estuaries and the Gulf of Mexico (C. chesapeakei), while circles represent animals

1005 taken from coastal Atlantic regions (C. quinquecirrha). Only animals with fully intact and

1006 extended oral arms were included. All animals with $16 S$ sequences matching the $C$. chesapeakei

1007 clade appear in red, while those whose sequences matched the C. quinquecirrha clade appear in

1008 blue. C) Average size measurements for holotrichous A-isrohiza nematocysts (length vs. width),

1009 based on 10 nematocysts per. Error bars represent $95 \%$ confidence intervals ( $2 *$ standard error).

1010 Squares represent nematocysts from estuarine Atlantic and Gulf of Mexico medusae $(C$.

1011 chesapeakei), while circles represent nematocysts from coastal Atlantic medusae (C.

1012 quinquecirrha). Photograph of an average sized A-isorhiza from C. quinquecirrha appears on the

1013 left and a photograph of an average size A-isorhiza from C. chesapeakei appears on the right.

1014 Scale bars=10 um. Photographs have been resized so that all error bars are the same size on the

1015 page to allow size comparisons. All animals with $16 S$ sequences matching the C. chesapeakei 
1016 clade appear in red, while those whose sequences matched the C. quinquecirrha clade appear in

1017 blue. Triangles represent average values from Papenfuss (1936) for morphs identified as

1018 Dactylometra quinquecirrha (gray) or Dactylometra quinquecirrha var. chesapeakei (white).

1019

1020 Figure 9: Pelagiidae Evolution. Cladograms showing genus-level relationships within the

1021 Pelagiidae family. Colors represent individual genera as shown. A) Gershwin and Collins (2002);

1022 B) Morandini and Marques (2010); C) Avian et al. (2016): DNA analysis based on nuclear 28S;

1023 D) Avian et al. (2016): morphological analyses only; E) This study: Combined DNA analysis

1024 using sequence data from COI, $16 S$ and $28 S . *$ In Avian et al. (2016), this sequence is marked as

1025 Chrysaora sp. AY920779. This sequence is included in our analysis and is part of the clade that

1026 we call Chrysaora c.f. chesapeakei. ${ }^{\wedge}$ We include the $28 S$ phylogeny from Avian et al. (2016)

1027 because it has more species than their combined analysis but their generic conclusions are

1028 identical. Note that all previous hypotheses include a monophyletic Chrysaora.

1029

1030

1031

1032

1033

1034

1035

1036

1037

1038 


\section{REFERENCES}

1040 Agassiz A. 1865. North American Acelephae. Illustrated Catalogue of the Museum of

1041

1042 Comparative Zoology at Harvard College 2:1-234.

1043

1044

1045

1046

1047

1048

1049

1050

1051

1052

1053

1054

1055

1056

1057

1058

1059

1060

1061

1062

1063

1064

1065

1066

1067

1068

1069

1070

1071

1072

1073

1074

1075

1076

1077

1078

1079

1080

1081

1082

1083

Agassiz A, and Mayer A. 1898. On Dactylometra. Bulletin of the Museum of Comparative Zoology at Harvard College 32:1-11.

Agassiz L. 1862. Contributions to the natural history of the United States of America. IV. Boston: Little, Brown and Company.

Altschul SF, Madden TL, Schaffer AA, Zhang J, Zhang Z, Miller W, and Lipman DJ. 1997. Gapped BLAST and PSI-BLAST: a new generation of protein database search programs. Nucleic acids research 25:3389.

Antit M, Gofas S, and Azzouna A. 2010. A gastropod from the tropical Atlantic becomes an established alien in the Mediterranean. Biological Invasions 12:991-994.

Arai M. 1997. A Functional Biology of Scyphozoa. London: Chapman and Hall.

Arai MN. 2005. Predation on pelagic coelenterates: a review. Journal of the Marine Biological Association of the United Kingdom 85:523-536.

Ausubel FM, Brent R, Kingston RF, Moore DD, Seidman JG, Smith JA, and Struhl K. 1989. Current Protocols in Molecular Biology. New York: Wiley and Sons.

Avian M, Ramšak A, Tirelli V, D’Ambra I, and Malej A. 2016. Redescription of Pelagia benovici into a new jellyfish genus, Mawia, gen. nov., and its phylogenetic position within Pelagiidae (Cnidaria: Scyphozoa: Semaeostomeae). Invertebrate Systematics 30:523-546.

Bayha KM, and Dawson MN. 2010. New family of allomorphic jellyfishes, Drymonematidae (Scyphozoa, Discomedusae), emphasizes evolution in the functional morphology and trophic ecology of gelatinous zooplankton. The Biological Bulletin 219:249-267.

Bayha KM, Dawson MN, Collins AG, Barbeitos MS, and Haddock SHD. 2010. Evolutionary relationships among scyphozoan jellyfish families based on complete taxon sampling and phylogenetic analyses of $18 S$ and $28 S$ ribosomal DNA. Integrative and Comparative Biology 50:436-455.

Bayha KM, and Graham WM. 2009. A new Taqman(C PCR-based method for the detection and identification of scyphozoan jellyfish polyps. Hydrobiologia 616:217-228.

Bayha KM, and Graham WM. 2014. Nonindigenous marine jellyfish: invasiveness, invasibility, and impacts. In: Pitt KA, and Lucas CH, eds. Jellyfish Blooms. Dordrecht: Springer, 45-77.

Ben Souissi J, Zaouali J, Rezig M, Bradai M, Quignard J, and Rudman B. 2004. Contribution à l'étude de quelques récentes migrations d'espèces exotiques dans les eaux tunisiennes. Rapports de la Commission Internationale pour l'Exploration Scientifique de la Mer Méditerranée 37:312.

Bigelow RP. 1880. A new Chrysaoran medusa. Johns Hopkins Circular 9:66.

Birsa LM, Verity PG, and Lee RF. 2010. Evaluation of the effects of various chemicals on discharge of and pain caused by jellyfish nematocysts. Comparative Biochemistry and Physiology Part C: Toxicology \& Pharmacology 151:426-430.

Blanquet RS, and Wetzel B. 1975. Surface ultrastructure of the scyphopolyp, Chrysaora quinquecirrha. Biological Bulletin 148:181-192.

Bloom D, Radwan F, and Burnett J. 2001. Toxinological and immunological studies of capillary electrophoresis fractionated Chrysaora quinquecirrha (Desor) fishing 
1084

1085

1086

1087

1088

1089

1090

1091

1092

1093

1094

1095

1096

1097

1098

1099

1100

1101

1102

1103

1104

1105

1106

1107

1108

1109

1110

1111

1112

1113

1114

1115

1116

1117

1118

1119

1120

1121

1122

1123

1124

1125

1126

1127

tentacle and Chironex fleckeri Southcott nematocyst venoms. Comparative Biochemistry and Physiology Part C: Toxicology \& Pharmacology 128:75-90.

Breitburg D, and Burrell R. 2014. Predator-mediated landscape structure: seasonal patterns of spatial expansion and prey control by Chrysaora quinquecirrha and Mnemiopsis leidyi. Marine Ecology Progress Series 510:183-200.

Breitburg DL, and Fulford RS. 2006. Oyster-sea nettle interdependence and altered control within the Chesapeake Bay ecosystem. Estuaries and Coasts 29:776-784.

Brooks WK. 1882. List of medusae found at Beaufort, NC, during the summers of 1880 and 1881. Studies from the Biological Laboratory of the Johns Hopkins University 2:135146.

Brotz L, and Pauly D. 2012. Jellyfish populations in the Mediterranean Sea. Acta Adriatica 53:213-230.

Brown CW, Hood RR, Long W, Jacobs J, Ramers DL, Wazniak C, Wiggert JD, Wood R, and Xu J. 2013. Ecological forecasting in Chesapeake Bay: using a mechanistic-empirical modeling approach. Journal of Marine Systems 125:113-125.

Burke WD. 1976. Biology and distribution of the macrocoelenterates of Mississippi Sound and adjacent waters. Gulf and Caribbean Research 5:17-28.

Burnett JW, Bloom DA, Imafuku S, Houck H, Vanucci S, Aurelian L, and Morris SC. 1996. Coelenterate venom research 1991-1995: clinical, chemical and immunological aspects. Toxicon 34:1377-1383.

Calder DR. 1971. Nematocysts of polyps of Aurelia, Chrysaora, and Cyanea, and their utility in identification. Transactions of the American Microscopical Society 90:269-274.

Calder DR. 1972. Development of the sea nettle Chrysaora quinquecirrha (Scyphozoa, Semaeostomeae). Chesapeake Science 13:40-44.

Calder DR. 1974a. Nematocysts of the coronate scyphomedusa, Linuche unguiculata, with a brief reexamination of scyphozoan nematocyst classification. Chesapeake Science 15:170-173.

Calder DR. 1974b. Strobilation of the sea nettle, Chrysaora quinquecirrha, under field conditions. The Biological Bulletin 146:326-334.

Calder DR. 1977. Nematocysts of the ephyra stages of Aurelia, Chrysaora, Cyanea, and Rhopilema (Cnidaria, Scyphozoa). Transactions of the American Microscopical Society:13-19.

Calder DR. 2009. Cubozoan and scyphozoan jellyfishes of the Carolinian biogeographic province, southeastern USA. Royal Ontario Museum Contributions in Science 3:1-58.

Canepa A, Fuentes V, Sabatés A, Piraino S, Boero F, and Gili J-M. 2014. Pelagia noctiluca in the Mediterranean Sea. In: Pitt KA, and Lucas CH, eds. Jellyfish Blooms. Dordrecht: Springer, 237-266.

Cargo D. 1979. Observations on the settling behavior of planular larvae of Chrysaora quinquecirrha. International Journal of Invertebrate Reproduction 1:279-287.

Cargo DG. 1975. Comments on the laboratory culture of Scyphozoa. In: Smith WL, and Chanley MH, eds. Culture of Marine Invertebrate Animals. New York: Plenum Press, 145-154.

Cargo DG, and King DR. 1990. Forecasting the abundance of the sea nettle, Chrysaora quinquecirrha, in the Chesapeake Bay. Estuaries 13:486-491. 
1128 Cargo DG, and Rabenold GE. 1980. Observations on the asexual reproductive activities of

1129

1130

1131

1132

1133

1134

1135

1136

1137

1138

1139

1140

1141

1142

1143

1144

1145

1146

1147

1148

1149

1150

1151

1152

1153

1154

1155

1156

1157

1158

1159

1160

1161

1162

1163

1164

1165

1166

1167

1168

1169

1170

1171

1172

1173 the sessile stages of the sea nettle Chrysaora quinquecirrha (Scyphozoa). Estuaries 3:20-27.

Cargo DG, and Schultz LP. 1966. Notes on the biology of the sea nettle, Chrysaora quinquecirrha, in Chesapeake Bay. Chesapeake Science 7:95-100.

Castresana J. 2000. Selection of conserved blocks from multiple alignments for their use in phylogenetic analysis. Molecular Biology and Evolution 17:540.

Castro JJ, Santiago JA, and Santana-Ortega AT. 2002. A general theory on fish aggregation to floating objects: an alternative to the meeting point hypothesis. Reviews in fish biology and fisheries 11:255-277.

Clifford HC, and Cargo DG. 1978. Feeding rates of the sea nettle, Chrysaora quinquecirrha, under laboratory conditions. Estuaries 1:58-61.

Condon RH, Decker MB, and Purcell JE. 2001. Effects of low dissolved oxygen on survival and asexual reproduction of scyphozoan polyps (Chrysaora quinquecirrha). Hydrobiologia 451:89-95.

Condon RH, Duarte CM, Pitt KA, Robinson KL, Lucas CH, Sutherland KR, Mianzan HW, Bogeberg M, Purcell JE, and Decker MB. 2013. Recurrent jellyfish blooms are a consequence of global oscillations. Proceedings of the National Academy of Sciences of the USA 110:1000-1005.

Condon RH, and Steinberg DK. 2008. Development, biological regulation, and fate of ctenophore blooms in the York River estuary, Chesapeake Bay. Marine Ecology Progress Series 369:153-168.

Condon RH, Steinberg DK, and Bronk DA. 2010. Production of dissolved organic matter and inorganic nutrients by gelatinous zooplankton in the York River estuary, Chesapeake Bay. Journal of Plankton Research 32:153-170.

Condon RH, Steinberg DK, Del Giorgio PA, Bouvier TC, Bronk DA, Graham WM, and Ducklow HW. 2011. Jellyfish blooms result in a major microbial respiratory sink of carbon in marine systems. Proceedings of the National Academy of Sciences of the USA 108:10225-10230.

Darriba D, Taboada GL, Doallo R, and Posada D. 2012. jModelTest 2: more models, new heuristics and parallel computing. Nature Methods 9:772-772.

Dawson MN. 2003. Macro-morphological variation among cryptic species of the moon jellyfish, Aurelia (Cnidaria: Scyphozoa). Marine Biology 143:369-379.

Dawson MN. 2005. Cyanea capillata is not a cosmopolitan jellyfish: morphological and molecular evidence for $C$. annaskala and $C$. rosea (Scyphozoa: Semaeostomeae: Cyaneidae) in south-eastern Australia. Invertebrate Systematics 19:361-370.

Dawson MN, Gupta AS, and England MH. 2005. Coupled biophysical global ocean model and molecular genetic analyses identify multiple introductions of cryptogenic species. Proceedings of the National Academy of Sciences of the USA 102:11968.

Dawson MN, and Jacobs DK. 2001. Molecular evidence for cryptic species of Aurelia aurita (Cnidaria, Scyphozoa). The Biological Bulletin 200:92-96.

Dawson MN, and Martin LE. 2001. Geographic variation and ecological adaptation in Aurelia (Scyphozoa, Semaeostomeae): some implications from molecular phylogenetics. Hydrobiologia 451:259-273.

Dawson MN, Raskoff KA, and Jacobs DK. 1998. Field preservation of marine invertebrate tissue for DNA analyses. Molecular Marine Biology and Biotechnology 7:145-152. 
1174 Decker MB, Brown CW, Hood RR, Purcell JE, Gross TF, Matanoski JC, Bannon RO, and

1175

1176

1177

1178

1179

1180

1181

1182

1183

1184

1185

1186

1187

1188

1189

1190

1191

1192

1193

1194

1195

1196

1197

1198

1199

1200

1201

1202

1203

1204

1205

1206

1207

1208

1209

1210

1211

1212

1213

1214

1215

1216

1217

1218
Setzler-Hamilton EM. 2007. Predicting the distribution of the scyphomedusa Chrysaora quinquecirrha in Chesapeake Bay. Marine Ecology Progress Series 329:99113.

Desor E. 1848. Hydroids from Nantucket. Proceedings of the Boston Society of Natural History 3:65-66.

Diaz Briz L, Sánchez F, Marí N, Mianzan H, and Genzano G. 2017. Gelatinous zooplankton (ctenophores, salps and medusae): an important food resource of fishes in the temperate SW Atlantic Ocean. Marine Biology Research. doi: 10.1080/17451000.2016.1274403

Doyle TK, Hays GC, Harrod C, and Houghton JD. 2014. Ecological and societal benefits of jellyfish. In: Pitt KA, and Lucas CH, eds. Jellyfish blooms. Dordrecht: Springer, 105127.

Duarte CM, Pitt KA, Lucas CH, Purcell JE, Uye S-i, Robinson K, Brotz L, Decker MB, Sutherland KR, and Malej A. 2012. Is global ocean sprawl a cause of jellyfish blooms? Frontiers in Ecology and the Environment 11:91-97.

Duffy JT, Epifanio CE, and Fuiman LA. 1997. Mortality rates imposed by three scyphozoans on red drum (Sciaenops ocellatus Linnaeus) larvae in field enclosures. Journal of Experimental Marine Biology and Ecology 212:123-131.

Eschscholtz F. 1829. System der Acalephen. Eine ausführliche Beschreibung aller medusen artigen Strahltiere. Berlin: Ferdinand Dümmler.

Feigenbaum D, and Kelly M. 1984. Changes in the lower Chesapeake Bay food chain in presence of the sea nettle Chrysaora quinquecirrha (Scyphomedusa). Marine Ecology Progress Series 19:39-47.

Fewkes JW. 1881. Studies of the jelly-fishes of Narragansett Bay. Bulletin of the Museum of Comparative Zoology at Harvard College 8:141-182.

Fish CJ. 1925. Seasonal distribution of the plankton of the Woods Hole region. Bulletin of the Bureau of Fisheries 41:91-179.

Flynn B, Richardson A, Brierley A, Boyer D, Axelsen B, Scott L, Moroff N, Kainge P, Tjizoo B, and Gibbons M. 2012. Temporal and spatial patterns in the abundance of jellyfish in the northern Benguela upwelling ecosystem and their link to thwarted pelagic fishery recovery. African Journal of Marine Science 34:131-146.

Ford M, Costello J, Heidelberg K, and Purcell J. 1997. Swimming and feeding by the scyphomedusa Chrysaora quinquecirrha. Marine Biology 129:355-362.

Frost JR, Jacoby CA, Frazer TK, and Zimmerman AR. 2012. Pulse perturbations from bacterial decomposition of Chrysaora quinquecirrha (Scyphozoa: Pelagiidae). Hydrobiologia 690:247-256.

Gegenbaur C. 1856. Versuch eines Systemes der Medusen, mit Bescheibung neuer oder wenig gekannter Formen. Zeitschrift für wissenschaftliche Zoologie 8:202-273.

Gershwin L, and Collins A. 2002. A preliminary phylogeny of Pelagiidae (Cnidaria, Scyphozoa), with new observations of Chrysaora colorata comb. nov. Journal of Natural History 36:127-148.

Goette A. 1886. Verzeichniss der Medusen welche von Dr Sander, Stabsarzt auf S.M.S. "Prinz Adalbert" gesammelt wurden. Sitzungsberichte der preussischen Akademie der Wissenschaften 7:831-837. 
1219 Gofas S, and Zenetos A. 2003. Exotic molluscs in the Mediterranean basin: current status

1220

1221

1222

1223

1224

1225

1226

1227

1228

1229

1230

1231

1232

1233

1234

1235

1236

1237

1238

1239

1240

1241

1242

1243

1244

1245

1246

1247

1248

1249

1250

1251

1252

1253

1254

1255

1256

1257

1258

1259

1260

1261

1262 and perspectives. In: Gibson R, and Atkinson R, eds. Oceanography and Marine Biology, An Annual Review. London: Taylor and Francis, 237-277.

Gouy M, Guindon S, and Gascuel 0. 2010. SeaView version 4: a multiplatform graphical user interface for sequence alignment and phylogenetic tree building. Molecular Biology and Evolution 27:221-224.

Graham W. 2001. Numerical increases and distributional shifts of Chrysaora quinquecirrha (Desor) and Aurelia aurita (Linné) (Cnidaria: Scyphozoa) in the northern Gulf of Mexico. Hydrobiolgia 451:97-111.

Grove M, and Breitburg DL. 2005. Growth and reproduction of gelatinous zooplankton exposed to low dissolved oxygen. Marine Ecology Progress Series 301:185-198.

Guindon S, Dufayard J-F, Lefort V, Anisimova M, Hordijk W, and Gascuel 0. 2010. New algorithms and methods to estimate maximum-likelihood phylogenies: assessing the performance of PhyML 3.0. Systematic Biology 59:307-321.

Hedgepeth J. 1954. Scyphozoa. Fishery Bulletin of the Fish and Wildlife Service, US 55:277278.

Holland BS, Dawson MN, Crow GL, and Hofmann DK. 2004. Global phylogeography of Cassiopea (Scyphozoa: Rhizostomeae): molecular evidence for cryptic species and multiple invasions of the Hawaiian Islands. Marine Biology 145:1119-1128.

Houck HE, Lipsky MM, Marzella L, and Burnett JV. 1996. Toxicity of sea nettle (Chrysaora quinquecirrha) fishing tentacle nematocyst venom in cultured rat hepatocytes. Toxicon 34:771-778.

Houghton JD, Doyle TK, Wilson MW, Davenport J, and Hays GC. 2006. Jellyfish aggregations and leatherback turtle foraging patterns in a temperate coastal environment. Ecology 87:1967-1972.

Hutton CH, Delisle PF, Roberts MH, and Hepworth DA. 1986. Chrysaora quinquecirrha: a predator on mysids (Mysidopsis bahia) in culture. The Progressive Fish Culturist 48:154-155.

ICZN. 1999. International Code of Zoological Nomenclature, 4th Edition. Padvoa: Tipografia La Garangola.

Ishikawa T, Vucenik I, Shamsuddin A, Niculescu F, and Burnett JW. 2004. Two new actions of sea nettle (Chrysaora quinquecirrha) nematocyst venom: studies on the mechanism of actions on complement activation and on the central nervous system. Toxicon 44:895-899.

Johnson DR, Perry HM, and Burke WD. 2001. Developing jellyfish strategy hypotheses using circulation models. Hydrobiologia 451:213-221.

Kaneshiro-Pineiro MY, and Kimmel DG. 2015. Local Wind Dynamics Influence the Distribution and Abundance of Chrysaora quinquecirrha in North Carolina, USA. Estuaries and Coasts 38:1965-1975.

Katoh K, and Standley DM. 2013. MAFFT multiple sequence alignment software version 7: improvements in performance and usability. Molecular Biology and Evolution 30:772-780.

Katoh K, and Toh H. 2008. Recent developments in the MAFFT multiple sequence alignment program. Briefings in Bioinformatics 9:286. 
1263 Kayal E, Bentlage B, Pankey MS, Ohdera A, Medina M, Pachetzki DC, Collins AG, and Ryan JF.

1264

1265

1266

1267

1268

1269

1270

1271

1272

1273

1274

1275

1276

1277

1278

1279

1280

1281

1282

1283

1284

1285

1286

1287

1288

1289

1290

1291

1292

1293

1294

1295

1296

1297

1298

1299

1300

1301

1302

1303

1304

1305

1306

1307

1308 2017. Comprehensive phylogenomic analyses resolve cnidarian relationships and the origins of key organismal traits. PeerJ Preprints 5:e3172v3171.

Kayal E, Roure B, Philippe H, Collins AG, and Lavrov DV. 2013. Cnidarian phylogenetic relationships as revealed by mitogenomics. BMC Evolutionary Biology 13:1.

Kimmel DG, Boynton WR, and Roman MR. 2012. Long-term decline in the calanoid copepod Acartia tonsa in central Chesapeake Bay, USA: An indirect effect of eutrophication? Estuarine, Coastal and Shelf Science 101:76-85.

Kimmel DG, Roman MR, and Zhang X. 2006. Spatial and temporal variability in factors affecting mesozooplankton dynamics in Chesapeake Bay: evidence from biomass size spectra. Limnology and Oceanography 51:131-141.

Kishinouye K. 1902. Some new Scyphomedusae of Japan. Journal of the College of Science, Imperial University, Tokyo 17:1-17.

Kolbasova GD, Zalevsky AO, Gafurov AR, Gusev PO, Ezhova MA, Zheludkevich AA, Konovalova OP, Kosobokova KN, Kotlov NU, and Lanina NO. 2015. A new species of Cyanea jellyfish sympatric to C. capillata in the White Sea. Polar Biology 38:14391451.

Kraeuter JN, and Setzler EM. 1975. The seasonal cycle of Scyphozoa and Cubozoa in Georgia estuaries. Bulletin of Marine Science 25:66-74.

Kramp PL. 1955. The medusae of the tropical west coast of Africa. Atlantide Report: Scientific Results of the Danish Expedition to the Coasts of Tropical West Africa, 19451946 2:239-324.

Kramp PL. 1961. Synopsis of the medusae of the world. Journal of the Marine Biological Association of the United Kingdom 40:7-382.

Kreps TA, Purcell J, and Heidelberg K. 1997. Escape of the ctenophore Mnemiopsis leidyi from the scyphomedusa predator Chrysaora quinquecirrha. Marine Biology 128:441446.

Kumar S, Stecher G, and Tamura K. 2016. MEGA7: Molecular Evolutionary Genetic Analysis version 7.0 for Bigger Datasets. Molecular Biology and Evolution 33:1870-1874.

Larkin MA, Blackshields G, Brown NP, Chenna R, McGettigan PA, McWilliam H, Valentin F, Wallace IM, Wilm A, and Lopez R. 2007. Clustal W and Clustal X version 2.0. Bioinformatics 23:2947.

Larson RJ. 1976. Marine Flora and Fauna of the Northeastern United States, Cnidaria: Scyphozoa. NOAA Technical Report NMFS Circular 397. Washington: US Department of Commerce, National Oceanic and Atmospheric Administration, National Marine Fisheries Service.

Lebrato M, Pitt KA, Sweetman AK, Jones DO, Cartes JE, Oschlies A, Condon RH, Molinero JC, Adler L, and Gaillard C. 2012. Jelly-falls historic and recent observations: a review to drive future research directions. Hydrobiologia 690:227-245.

Lee HE, Yoon WD, Chae J, and Ki J-S. 2016. Re-description of Chrysaora pacifica (Goette, 1886)(Cnidaria, Scyphozoa) from Korean Coastal Waters: Morphology and Molecular Comparisons. Ocean \& Polar Research 38:295-301.

Lin AL, and Zubkoff PL. 1976. Malate dehydrogenase isozymes of different stages of Chesapeake Bay jellyfish. The Biological Bulletin 150:268-278.

Littleford RA. 1939. The life cycle of Dactylometra quinquecirrha, L. Agassiz in the Chesapeake Bay. The Biological Bulletin 77:368-381. 
1309 Littleford RA, and Truitt R. 1937. Variation of Dactylometra quinquecirrha. Science 86:426427.

1311

1312

1313

1314

1315

1316

1317

1318

1319

1320

1321

1322

1323

1324

1325

1326

1327

1328

1329

1330

1331

1332

1333

1334

1335

1336

1337

1338

1339

1340

1341

1342

1343

1344

1345

1346

1347

1348

1349

1350

1351

1352

1353

Loeb MJ. 1972. Strobilation in the Chesapeake Bay sea nettle Chrysaora quinquecirrha. I. The effects of environmental temperature changes on strobilation and growth. Journal of Experimental Zoology 180:279-291.

Loeb MJ. 1973. The effect of light on strobilation in the Chesapeake Bay sea nettle Chrysaora quinquecirrha. Marine Biology 20:144-147.

Loeb MJ. 1974. Strobilation in the chesapeake bay sea nettle Chrysaora quinquecirrha-III. Dissociation of the neck-inducing factor from strobilating polyps. Comparative Biochemistry and Physiology Part A: Physiology 49:423-432.

Loeb MJ, and Blanquet RS. 1973. Feeding behavior in polyps of the Chesapeake Bay sea nettle, Chrysaora quinquecirrha (Desor, 1848). The Biological Bulletin 145:150-158.

Loeb MJ, and Gordon CM. 1975. Strobilation in the chesapeake bay sea nettle, Chrysaora quinquecirrha-IV. Tissue levels of iodinated high molecular weight component and nif in relation to temperature change-induced behavior. Comparative Biochemistry and Physiology Part A: Physiology 51:37-42.

Luque ÁA, Barrajón A, Remón JM, Moreno D, and Moro L. 2012. Marginella glabella (Mollusca: Gastropoda: Marginellidae): a new alien species from tropical West Africa established in southern Mediterranean Spain through a new introduction pathway. Marine Biodiversity Records 5:e17.

Lynam CP, and Brierley AS. 2007. Enhanced survival of 0-group gadoid fish under jellyfish umbrellas. Marine Biology 150:1397-1401.

Lynam CP, Gibbons MJ, Axelsen BE, Sparks CA, Coetzee J, Heywood BG, and Brierley AS. 2006. Jellyfish overtake fish in a heavily fished ecosystem. Current Biology 16:R492R493.

Matanoski J, Hood R, and Purcell J. 2001. Characterizing the effect of prey on swimming and feeding efficiency of the scyphomedusa Chrysaora quinquecirrha. Marine Biology 139:191-200.

Matanoski JC, and Hood RR. 2006. An individual-based numerical model of medusa swimming behavior. Marine Biology 149:595-608.

Mayer AG. 1910. Medusae of the World, III: the Scyphomedusae. Carnegie Institute, Washington.

Meredith RW, Gaynor JJ, and Bologna PA. 2016. Diet assessment of the Atlantic Sea Nettle Chrysaora quinquecirrha in Barnegat Bay, New Jersey, using next - generation sequencing. Molecular Ecology 25:6248-6266.

Meyer D, Zeileis A, and Hornik K. 2016. vcd: Visulaizing Categorical Data. R package version 14-3.

Mianzan H, Quiñones J, Palma S, Schiariti A, Acha EM, Robinson KL, and Graham WM. 2014. Chrysaora plocamia: a poorly understood jellyfish from South American waters. In: Pitt KA, and Lucas CH, eds. Jellyfish Blooms. Dordrecht: Springer, 219-236.

Morandini AC, and Marques AC. 2010. Revision of the genus Chrysaora Péron \& Lesueur, 1810 (Cnidaria: Scyphozoa). Zootaxa 2464:1-97.

Nemazie D, Purcell J, and Glibert P. 1993. Ammonium excretion by gelationous zooplankton and their contribution to the ammonium requirements of microplankton in Chesapeake Bay. Marine Biology 116:451-458. 
1354 Ohta N, Sato M, Ushida K, Kokubo M, Baba T, Taniguchi K, Urai M, Kihira K, and Mochida J.

1355 2009. Jellyfish mucin may have potential disease-modifying effects on osteoarthritis.

1356

1357

1358

1359

1360

1361

1362

1363

1364

1365

1366

1367

1368

1369

1370

1371

1372

1373

1374

1375

1376

1377

1378

1379

1380

1381

1382

1383

1384

1385

1386

1387

1388

1389

1390

1391

1392

1393

1394

1395

1396

1397

1398 BMC Biotechnology 9:1.

Olesen NJ, Purcell JE, and Stoecker DK. 1996. Feeding and growth by ephyrae of scyphomedusae Chrysaora quinquecirrha. Marine Ecoogy Progress Series 137:149159.

Omori M, and Nakano E. 2001. Jellyfish fisheries in southeast Asia. Hydrobiologia 451:1926.

Östman C, and Hydman J. 1997. Nematocyst analysis of Cyanea capillata and Cyanea lamarckii (Scyphozoa, Cnidaria). Scientia Marina 61:313-344.

Papenfuss EJ. 1936. The Utility of the Nematocysts in the Classification of Certain Scyphomedusae. I. Cyanea capillata, Cyanea palmstruchii, Dactylometra quinquecirrha, Dactylometra quinquecirrha var. chesapeakei, and Chrysaora hysoscella. Acta Universitatis Lundensis, Nova Series 31:19-26.

Péron F, and Lesueur C. 1810. Tableau des caractères génériques et spécifiques de toutes les espèces de Méduses connues jusqu'à ce jour. Annales du Muséum National d'Histoire Naturelle, Paris 14:325-366.

Perry HM, and Larson K. 2004. A Picture Guide to Shelf Invertebrates from the Northern Gulf of Mexico. Available at http://www.gsmfc.org/seamap-pg.php (accessed (03/13/2017).

Persad G, Hopcroft RR, Webber MK, and Roff JC. 2003. Abundance, biomass and production of ctenophores and medusae off Kingston, Jamaica. Bulletin of Marine Science 73:379-396.

Piraino S, Aglieri G, Martell L, Mazzoldi C, Melli V, Milisenda G, Scorrano S, and Boero F. 2014. Pelagia benovici sp. nov.(Cnidaria, Scyphozoa): a new jellyfish in the Mediterranean Sea. Zootaxa 3794:455-468.

Purcell JE. 1992. Effects of predation by the scyphomedusan Chrysaora quinquecirrha on zooplankton populations in Chesapeake Bay, USA. Marine Ecology-Progress Series 87:65-65.

Purcell JE. 1997. Pelagic cnidarians and ctenophores as predators: selective predation, feeding rates, and effects on prey populations. Annales de l'Institut océanographique 73:125-137.

Purcell JE. 2007. Environmental effects on asexual reproduction rates of the scyphozoan Aurelia labiata. Marine Ecology Progress Series 348:183-196.

Purcell JE. 2009. Extension of methods for jellyfish and ctenophore trophic ecology to large-scale research. Hydrobiologia 616:23-50.

Purcell JE, Cresswell FP, Cargo DG, and Kennedy VS. 1991. Differential ingestion and digestion of bivalve larvae by the scyphozoan Chrysaora quinquecirrha and the ctenophore Mnemiopsis leidyi. The Biological Bulletin 180:103-111.

Purcell JE, and Decker MB. 2005. Effects of climate on relative predation by scyphomedusae and ctenophores on copepods in Chesapeake Bay during 1987 - 2000. Limnology and Oceanography 50:376-387.

Purcell JE, Malej A, and Benović A. 1999. Potential links of jellyfish to eutrophication and fisheries. In: Malone TC, Malej A, Harding Jr. LW, Smodlaka N, and Eugene Turner R, eds. Ecosystems at the land-sea margin: drainage basin to coastal sea: drainage basis 
1399

1400

1401

1402

1403

1404

1405

1406

1407

1408

1409

1410

1411

1412

1413

1414

1415

1416

1417

1418

1419

1420

1421

1422

1423

1424

1425

1426

1427

1428

1429

1430

1431

1432

1433

1434

1435

1436

1437

1438

1439

1440

1441

1442

1443

to coastal sea Coastal and Estuarine Studies, Vol 55. Washington: American Geophysical Union, 241-263.

Purcell JE, Uye S, and Lo WT. 2007. Anthropogenic causes of jellyfish blooms and their direct consequences for humans: a review. Marine Ecology Progress Series 350:153174.

Purcell JE, White JR, Nemazie DA, and Wright DA. 1999. Temperature, salinity and food effects on asexual reproduction and abundance of the scyphozoan Chrysaora quinquecirrha. Marine Ecology-Progress Series 180:187-196.

Purcell JE, White JR, and Roman MR. 1994. Predation by gelatinous zooplankton and resource limitation as potential controls of Acartia tonsa copepod populations in Chesapeake Bay. Limnology and Oceanography 39:263-278.

Qu C-F, Song J-M, Li N, Li X-G, Yuan H-M, Duan L-Q, and Ma Q-X. 2015. Jellyfish (Cyanea nozakii) decomposition and its potential influence on marine environments studied via simulation experiments. Marine Pollution Bulletin 97:199-208.

Rambaut A. 2014. Figtree v1.4.2 (Accessed March 2017).

Reynaud AAM. 1830. Medusa (Rhyzostoma) fulgida. In: Lesson RP, ed. Centurie Zoologique, ou choix d'animaux rares, nouveaux ou imparfaitement connus. Paris: F.G. Levrault, 79-80.

Rice NE, and Powell WA. 1970. Observations on three species of jellyfishes from Chesapeake Bay with special reference to their toxins. I. Chrysaora (Dactylometra) quinquecirrha. The Biological Bulletin 139:180-187.

Richardson AJ, Bakun A, Hays GC, and Gibbons MJ. 2009. The jellyfish joyride: causes, consequences and management responses to a more gelatinous future. Trends in Ecology \& Evolution 24:312-322.

Robinson KL, and Graham WM. 2013. Long-term change in the abundances of northern Gulf of Mexico scyphomedusae Chrysaora sp. and Aurelia spp. with links to climate variability. Limnology and Oceanography 58:235-253.

Ronquist F, Teslenko M, van der Mark P, Ayres DL, Darling A, Höhna S, Larget B, Liu L, Suchard MA, and Huelsenbeck JP. 2012. MrBayes 3.2: efficient Bayesian phylogenetic inference and model choice across a large model space. Systematic Biology 61:539-542.

Roux J-P, van der Lingen CD, Gibbons MJ, Moroff NE, Shannon LJ, Smith AD, and Cury PM. 2013. Jellyfication of marine ecosystems as a likely consequence of overfishing small pelagic fishes: lessons from the Benguela. Bulletin of Marine Science 89:249-284.

Schroth W, Jarms G, Streit B, and Schierwater B. 2002. Speciation and phylogeography in the cosmopolitan marine moon jelly, Aurelia sp. BMC Evolutionary Biology 2:1.

Schultz LP, and Cargo DG. 1969. Sea nettle barriers for bathing beaches in upper Chesapeake Bay: Natural Resources Institute, University of Maryland.

Segura-Puertas L, Suárez-Morales E, and Celis L. 2003. A checklist of the Medusae (Hydrozoa, Scyphozoa and Cubozoa) of Mexico. Zootaxa 194:1-15.

Sexton MA. 2012. Factors influencing appearance, disappearance, and variability of abundance of the sea nettle Chrysaora quinquecirrha in Chesapeake Bay Ph.D. University of Delaware.

Sexton MA, Hood RR, Sarkodee-adoo J, and Liss AM. 2010. Response of Chrysaora quinquecirrha medusae to low temperature. Hydrobiologia 645:125-133. 
1444 Stiasny G. 1930. Über Dactylometra fulgida (Renaud) von der Walfischbai. Zoologische

1445

1446

1447

1448

1449

1450

1451

1452

1453

1454

1455

1456

1457

1458

1459

1460

1461

1462

1463

1464

1465

1466

1467

1468

1469

1470

1471 Anzeiger 126:172-185.

Suchman CL, and Sullivan BK. 1998. Vulnerability of the copepod Acartia tonsa to predation by the scyphomedusa Chrysaora quinquecirrha: effect of prey size and behavior. Marine Biology 132:237-245.

Sutton JS, and Burnett JW. 1969. A light and electron microscopic study of nematocytes of Chrysaora quinquecirrha. Journal of Ultrastructure Research 28:214-234.

Tay J, and Hood RR. 2017. Abundance and patchiness of Chrysaora quinquecirrha medusae from a high-frequency time series in the Choptank River, Chesapeake Bay, USA. Hydrobiologia 792:227-242.

Thuesen EV, Rutherford LD, Brommer PL, Garrison K, Gutowska MA, and Towanda T. 2005. Intragel oxygen promotes hypoxia tolerance of scyphomedusae. Journal of Experimental Biology 208:2475-2482.

Vanhöffen E. 1902. Die Acraspeden Medusen de deutschen Tiefsee-expedition 1898-1899. Wissenschaftliche Ergebnisse der deutschen Tiefsee-expedition auf dem dampfer Valdivia 1898-1899 3:3-52.

Venables WN, and Ripley BD. 2002. Modern Applied Statistics with S, Fourth Edition. New York: Springer.

Weill R. 1934. Contribution à l' étude des cnidaires et de leurs nématocystes. I, II. Travaux de la Station Zoologique de Wimereux 10/11:1-701.

Wright DA, and Purcell DA. 1997. Effect of salinity on ionic shifts in mesohaline scyphomedusae, Chrysaora quinquecirrha. The Biological Bulletin 192:332-339.

Zenetos A, Gofas S, Morri C, Rosso A, Violanti D, Raso J, Çinar M, Almogi-Labin A, Ates A, and Azzurro E. 2012. Alien species in the Mediterranean Sea by 2012. A contribution to the application of European Union's Marine Strategy Framework Directive (MSFD). Part 2. Introduction trends and pathways. Mediterranean Marine Science 13:328352. 


\section{Table $\mathbf{1}$ (on next page)}

Geographic source regions of samples used for molecular analyses in this study, identified by taxon (original, morphologically based identification) and molecular ID (identification after molecular analyses).

For six individuals, $28 \mathrm{~S}$ sequences from those individuals were published previously. For $S$. malayensis, $16 \mathrm{~S} / \mathrm{CO}$ and $28 \mathrm{~S}$ sequences came from the same culture, but two different individuals. For some aquarium specimens, the geographic source region for the culture is known: *near Los Angeles, CA (USA); ^ Northern Malaysia; ${ }^{+}$near Monterey Bay, CA (USA). 
Table 1: Geographic source regions of samples used for molecular analyses in this study, identified by taxon (original,

morphologically based identification) and molecular ID (identification after molecular analyses). For six individuals, 28S sequences from those individuals were published previously. For $S$. malayensis, $16 \mathrm{~S} / \mathrm{COI}$ and $28 \mathrm{~S}$ sequences came from the same culture, but two different individuals. For some aquarium specimens, the geographic source region for the culture is known: *near Los Angeles, 5 CA (USA); ^Northern Malaysia; ${ }^{+}$near Monterey Bay, CA (USA).

\begin{tabular}{|c|c|c|c|c|c|c|}
\hline \multirow[b]{2}{*}{ Original ID } & \multirow[b]{2}{*}{ Final ID } & \multirow[b]{2}{*}{ Location } & \multirow[b]{2}{*}{ Code } & \multicolumn{3}{|c|}{$n$} \\
\hline & & & & COI & $16 \mathrm{~S}$ & $28 \mathrm{~S}$ \\
\hline Chrysaora achlyos & C. achlyos & Monterey Bay Aquarium* & MBA & 1 & 1 & 1 \\
\hline Chrysaora africana & C. africana & Coastal Namibia & NAM & 2 & 2 & 2 \\
\hline Chrysaora chinensis & C. chinensis & Monterey Bay Aquarium^ & MBA & 2 & 2 & 2 \\
\hline Chrysaora colorata & C. colorata & Aquarium of the Americas ${ }^{+}$ & AQA & 1 & 1 & 1 \\
\hline Chrysaora fulgida & C. fulgida & Coastal Namibia & NAM & 5 & 5 & 2 \\
\hline Chrysaora fuscescens & C. fuscescens & Aquarium of the Americas ${ }^{+}$ & AQA & 1 & 1 & HM194868 \\
\hline Chrysaora hysoscella & C. hysoscella & Cork, Ireland & IRE & 3 & 3 & 3 \\
\hline Chrysaora lactea & Chrysaora c.f. chesapeakei & Kingston, Jamaica & JAM & 5 & 5 & 2 \\
\hline Chrysaora lactea & C. lactea & Rio de la Plata, Argentina & $\mathrm{ARG}$ & 1 & 1 & 1 \\
\hline Chrysaora melanaster & C. melanaster & Bering Sea & BER & - & 1 & AY920780 \\
\hline Chrysaora melanaster & C. pacifica & Monterey Bay Aquarium & MBA & 1 & 1 & HM194864 \\
\hline Chrysaora plocamia & C. plocamia & Puerto Madryn, Argentina & PMA & 2 & 2 & 2 \\
\hline Chrysaora quinquecirrha & C. quinquecirrha & Buzzard's Bay, MA (USA) & MA & 1 & 1 & 1 \\
\hline Chrysaora quinquecirrha & C. quinquecirrha & Cape Henlopen, DE (USA) & $\mathrm{CHP}$ & 3 & 3 & 2 \\
\hline Chrysaora quinquecirrha & C. quinquecirrha & $\begin{array}{l}\text { Offshore South Carolina (USA) } \\
(32.60 \mathrm{~N}, 79.21 \mathrm{~W})\end{array}$ & OSC & 2 & 2 & 1 \\
\hline Chrysaora quinquecirrha & C. chesapeakei & Charlestown Pond, RI (USA) & RI & 4 & 4 & - \\
\hline Chrysaora quinquecirrha & C. chesapeakei & Tom's River Harbor, NJ (USA) & NJ & 3 & 3 & 1 \\
\hline Chrysaora quinquecirrha & C. chesapeakei & Rehoboth Bay, DE (USA) & $\mathrm{RB}$ & 3 & 3 & - \\
\hline Chrysaora quinquecirrha & C. chesapeakei & Norfolk, VA (USA) & NF & 5 & 5 & - \\
\hline Chrysaora quinquecirrha & C. chesapeakei & Pamlico Sound, NS (USA) & PAM & 3 & 3 & - \\
\hline Chrysaora quinquecirrha & C. chesapeakei & St. Simon's Island, GA (USA) & GA & 3 & 3 & 1 \\
\hline Chrysaora quinquecirrha & C. chesapeakei & Perdido Pass, AL (USA) & $\mathrm{AL}$ & 3 & 3 & 1 \\
\hline Pelagia noctiluca & P. noctiluca & $\begin{array}{l}\text { Offshore Virginia (USA) } \\
(37.81 \mathrm{~N}, 73.91 \mathrm{~W})\end{array}$ & OVA & 1 & 1 & HM194865 \\
\hline Sanderia malayensis & S. malayensis & Monterey Bay Aquarium & MBA & 1 & 1 & HM194861 \\
\hline Unknown Pelagiidae & M. benovici & Dakar, Senegal & SEN & 2 & 2 & 1 \\
\hline Cyanea capillata & C. capillata & Blomsterdalen, Norway & BLO & 1 & 1 & HM194873 \\
\hline
\end{tabular}




\section{Table 2 (on next page)}

Geographic source regions of previously published sequences used in in this study identified by taxon (previous identification) and Molecular ID (identification after molecular analyses).

*Sequences came from the same individual. 
Table 2: Geographic source regions of previously published sequences used in in this study identified by taxon (previous identification) and Molecular ID (identification after molecular analyses). *Sequences came from the same individual.

\begin{tabular}{|c|c|c|c|c|c|c|}
\hline \multirow[b]{2}{*}{ Original ID } & \multirow[b]{2}{*}{ Final ID } & \multirow[b]{2}{*}{ Location } & \multirow[b]{2}{*}{ Code } & \multicolumn{3}{|c|}{$n$} \\
\hline & & & & COI & $16 S$ & $28 S$ \\
\hline Chrysaora melanaster & C. melanaster & Bering Sea & BER1 & KJ026191 & - & - \\
\hline Chrysaora melanaster & C. melanaster & Bering Sea & BER2 & KJ026212 & - & - \\
\hline Chrysaora melanaster & C. melanaster & Bering Sea & BER3 & KJ026256 & - & - \\
\hline Chrysaora sp. & Chrysaora c.f. chesapeakei & Bocas del Toro, Panama & PAN & JN700941* & JN700941* & AY920779* \\
\hline Chrysaora pacifica & Chrysaora pacifica & Kyoto, Japan & KYO & LC191577 & - & - \\
\hline $\begin{array}{l}\text { Chrysaora } \\
\text { quinquecirrha }\end{array}$ & C. pacifica & Geoje-do, Korea & KOR & HQ0694730 & HQ0694730 & - \\
\hline Chrysaora sp. & Chrysaora sp. 1 & Noosa Heads, Australia & AUS & DQ083524 & - & - \\
\hline Chrysaora sp. & C. chinensis & Malaysia & MAL1 & - & JN184784 & - \\
\hline Chrysaora sp. & C. chinensis & Malaysia & MAL2 & - & JN184785 & - \\
\hline Chrysaora sp. & C. chinensis & Malaysia & MAL3 & - & JN184786 & - \\
\hline Pelagia benovici & P. benovici & Northern Adriatic Sea & ADR1 & KJ573409 & - & KJ573396 \\
\hline Pelagia benovici & P. benovici & Northern Adriatic Sea & ADR2 & KJ573410 & - & KJ573397 \\
\hline Pelagia benovici & P. benovici & Northern Adriatic Sea & ADR3 & KJ573412 & - & KJ573401 \\
\hline Pelagia noctiluca & P. noctiluca & Southern Tyrrhenian Sea, Italy & TYR & KJ573419 & - & KJ573408 \\
\hline Pelagia noctiluca & P. noctiluca & Cape Town, South Africa & SA & JQ697961 & - & - \\
\hline Pelagia noctiluca & P. noctiluca & Dispensa Island, Costa Rica & CR1 & JX235441 & - & - \\
\hline Pelagia noctiluca & P. noctiluca & Dispensa Island, Costa Rica & CR2 & - & JX235404 & - \\
\hline Pelagia noctiluca & P. noctiluca & Dispensa Island, Costa Rica & CR3 & - & JX235405 & - \\
\hline $\begin{array}{l}\text { Pelagia c.f. panopyra } \\
4\end{array}$ & Pelagia c.f. panopyra & Papua, New Guinea & PNG & KJ573422 & - & - \\
\hline
\end{tabular}




\section{Table 3 (on next page)}

Morphological characters examined for this study

Characters in bold are species diagnostic. All macromorpholgical characters and character states (except maximum oral arm length) are taken from Gershwin and Collins (2002). Cnidome terminology is taken from Morandini and Marques (2010), with average examples in Figure 8C, S1. *If two outlier specimens are included, the upper range is 6 tentacles/octant. ^Although maximum bell diameter for $C$. quinquecirha has been recorded as great as $40 \mathrm{~mm}$ (Gershwin and Collins, 2002; Morandini and Marques, 2010), no animals $>20 \mathrm{~mm}$ were observed in this study. 
1 Table 3: Morphological characters examined for this study. Characters in bold are species diagnostic. All

2 macromorpholgical characters and character states (except maximum oral arm length) are taken from

3 Gershwin and Collins (2002). Cnidome terminology is taken from Morandini and Marques (2010), with

4 average examples in Figure 8C, S1. *If two outlier specimens are included, the upper range is 6

5 tentacles/octant. ^Although maximum bell diameter for $C$. quinquecirha has been recorded as great as 40

$6 \mathrm{~mm}$ (Gershwin and Collins, 2002; Morandini and Marques, 2010), no animals $>20 \mathrm{~mm}$ were observed in

7 this study.

8

Character

\section{Macromorphology}

Bell Diameter (average/median)

Tentacles / octant (average $\pm 95 \%$ CI)

Tentacles / octant (range)

Lappets / octant (average \pm 95\% CI)

Lappets / octant (range)

Maximum Oral Arm Length (average $\pm 95 \% \mathrm{CI})$

Maximum Oral Arm Length (range)

Lappets in Size Classes

Rhopalia Number

Rhopaliar Pits

Septa Shape

Septa Termination

Spiral Oral Arms?

Manubrium Length

Manubrium Mass

Warts/Papillae

Maximum Bell Diameter

Bell Mass

Dominant color

Exumbrellar marks

Oral arm color

Quadralinga

Gonads in Pouch?

Gonad Shape

\section{Cnidome}

A isorhiza - Length vs. Width (avg)

A isorhiza - Length vs. Width (range)

a isorhiza - Length vs. Width (avg)

a isorhiza - Length vs. Width (range)

$\mathrm{O}$ isorhiza - Length vs. Width (avg)

$\mathrm{O}$ isorhiza - Length vs. Width (range)

Birhopaloids - Length vs. Width (avg)

Birhopaloids - Length vs. Width (range)
Chrysaora quinquecirrha

$114 \mathrm{~mm}(59-176 \mathrm{~mm})$

$5.28 \pm 0.45$

$4.5-6.75$

$6.26 \pm 0.46$

$5.5-7.75$

$1.24 \pm 0.27$ times BD

0.68 to 1.81 times BD

Yes, rhopalar lappets larger 8

deep

bent

near tentacle

No

elongated

light

inconspicuous

$<20 \mathrm{~cm}^{\wedge}$

light

White, colorless

Minor bell marks in some cases

None

None

Yes

Not finger-like

$20.25 \pm 0.38 \times 11.27 \pm 0.37 \mu \mathrm{m}$ 15.01-22.9 x 9.07-13.16 $\mu \mathrm{m}$ $8.27 \pm 0.19 \times 4.22 \pm 0.07 \mu \mathrm{m}$ 6.56-9.77 x 3.65-4.95 $\mu \mathrm{m}$

$21.64 \pm 0.38 \times 18.92 \pm 0.77 \mu \mathrm{m}$

$17.64-23.97 \times 16.08-21.74 \mu \mathrm{m}$

$13.58 \pm 0.19 \times 8.09 \pm 0.09 \mu \mathrm{m}$

$12.31-14.86 \times 6.96-8.90 \mu \mathrm{m}$
C. chesapeakei

$62.2 \mathrm{~mm}(17-175 \mathrm{~mm})$

$\mathbf{3 . 0 7} \pm \mathbf{0 . 0 7}$

$2.75-3.43 *$

$4.08 \pm 0.06$

$3.75-4.8$

$3.00 \pm 0.39$ times BD

1.21 to 5.58 timed BD

No, lappets of similar size

8

deep

bent

near tentacle

No

elongated

light

inconspicuous

$<20 \mathrm{~cm}^{\wedge}$

light

Variable, white, colorless or $\mathrm{red} /$ brown bell

Variable, red or brown star shape conspicuous in some cases, Variable, Oral arms can be colored red/brown

None

Yes

Not finger-like

$26.21 \pm 0.50 \times 19.74 \pm 0.55 \mu \mathrm{m}$

20.54-33.79 x 15.03-29.77 $\mu \mathrm{m}$

$7.88 \pm 0.13 \times 4.29 \pm 0.07 \mu \mathrm{m}$

$6.32-9.9 \times 3.59-5.46 \mu \mathrm{m}$

$23.10 \pm 0.43 \times 20.75 \pm 0.62 \mu \mathrm{m}$

$17.88-27.51 \times 16.07-24.75 \mu \mathrm{m}$

$12.73 \pm 0.22 \times 8.29 \pm 0.13 \mu \mathrm{m}$

$10.96-15.27 \times 7.1-10.23 \mu \mathrm{m}$ 


\section{Figure 1 (on next page)}

World map showing collecting sites of animals sequenced for this study

Final species designations are employed. All aquarium samples $(C$. achlyos, $C$. chinensis, $C$. colorata, C. fuscescens and C. pacifica) originated from cultures at the Monterey Bay Aquarium, although some were obtained from the Aquarium of the Americas. Their locations on the map are based on original collection locations for the aquarium cultures (W. Patry, pers. comm.). 


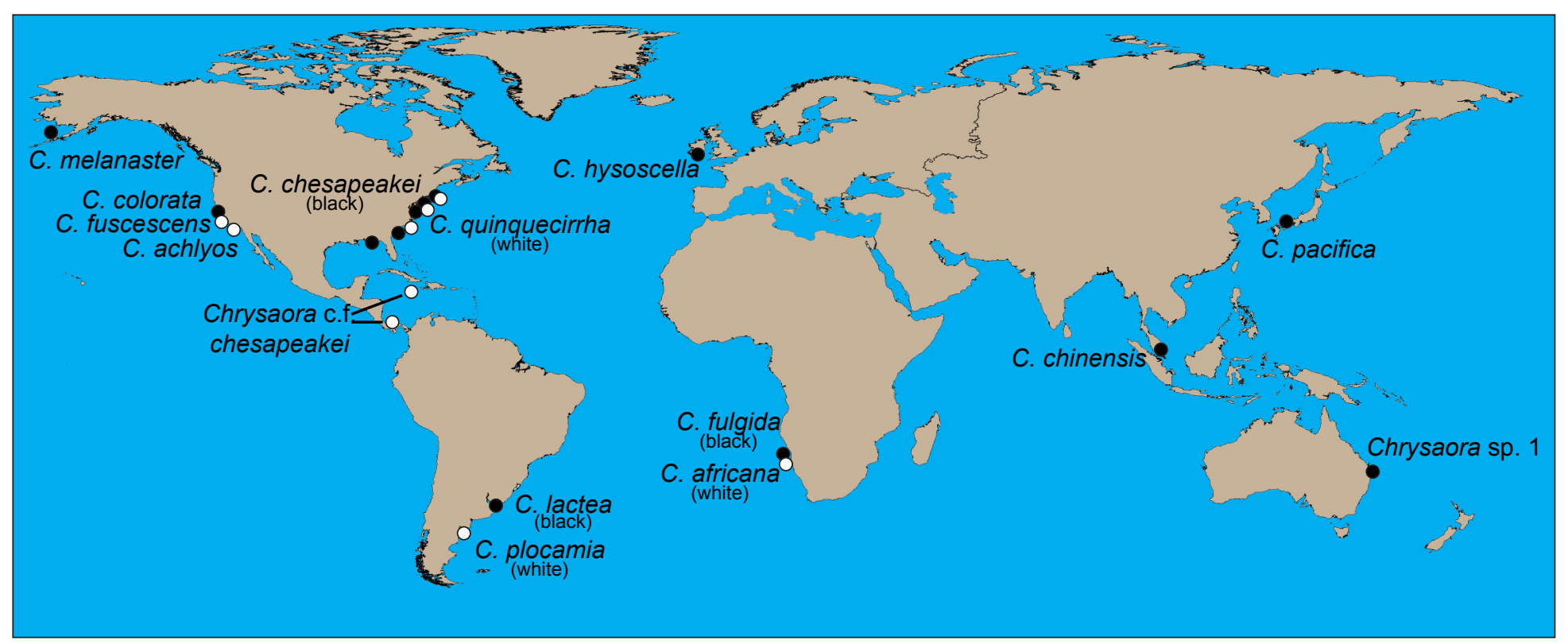




\section{Figure 2 (on next page)}

Collection locations of Chrysaora quinquecirrha s.I. medusae used in this study.

Abbreviations all refer to Tables 1 and S1. Figures 2 (A-C) are enlargements of rectangular inset regions. The star at Nantucket harbor indicates the type locality of $C$. quinquecirrha (Desor, 1848). Diamonds represent important museum collection sites (Table S1). Site RI is within the enclosed Charlestown Pond, RI (41.364.765 N, 71.628865 W). Site NJ is at Ocean Gate Yacht Club (39.930490 N, 74.140448 W) on Toms River, inside Barnegat Bay. Site RB was collected from inside Rehoboth Bay, DE (38.688091 N, 75.077114 W). All Chesapeake Bay samples (NF and Gloucester Point, VA) were taken from well within the Chesapeake Bay. Site PAM was collected from Englehard, NC (35.509102 N, 75.989712 W), well within Pamlico Sound. CST was taken from within Charleston Harbor (32.786995 N, 79.909297 W). Site GA was taken from Fancy Bluff Creek, upstream from Saint Simons Sound, GA (31.166291 N, $81.416032 \mathrm{~W}$ ). Sample sites with individuals finally designated as $C$. quinquecirrha are in white and those with individuals finally designated as $C$. chesapeakei in black. 


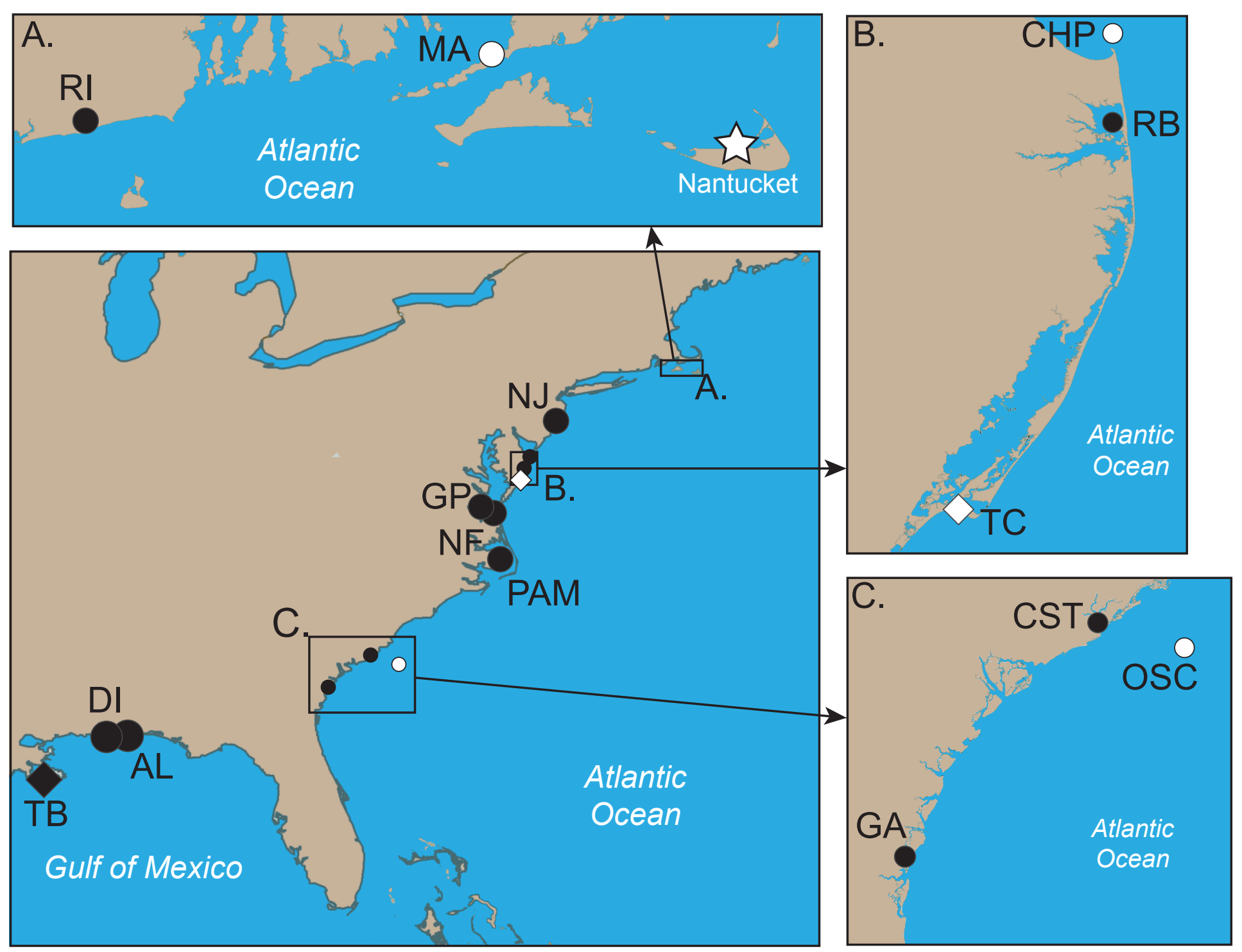




\section{Figure 3}

Various morphs of $C$. quinquecirrha s.l.

A) Offshore South Carolina (OSC); B) Sample taken from offshore Georgia; C) Englehard, NC (PAM); D) White Chesapeake Bay color morph (Broome's Island, MD - Patuxent River); E) Redstriped Chesapeake Bay color morph (Solomons, MD-Patuxent River). Note that medusae from A-B have 5 tentacles per octant, while C-E have three tentacles per octant. Medusae in $3 \mathrm{~A}$ and $3 \mathrm{C}$ were included in this study's phylogenetic analyses. (3A: OSC1; 3C: PAM1). A-B represent individuals finally designated as $C$. quinquecirrha; $C$-E represent individuals finally designated as C. chesapeakei. Photo Credits: 3A) Shannon Howard; 3B) Greg McFall-NOAA; 3E) Robert Condon. 

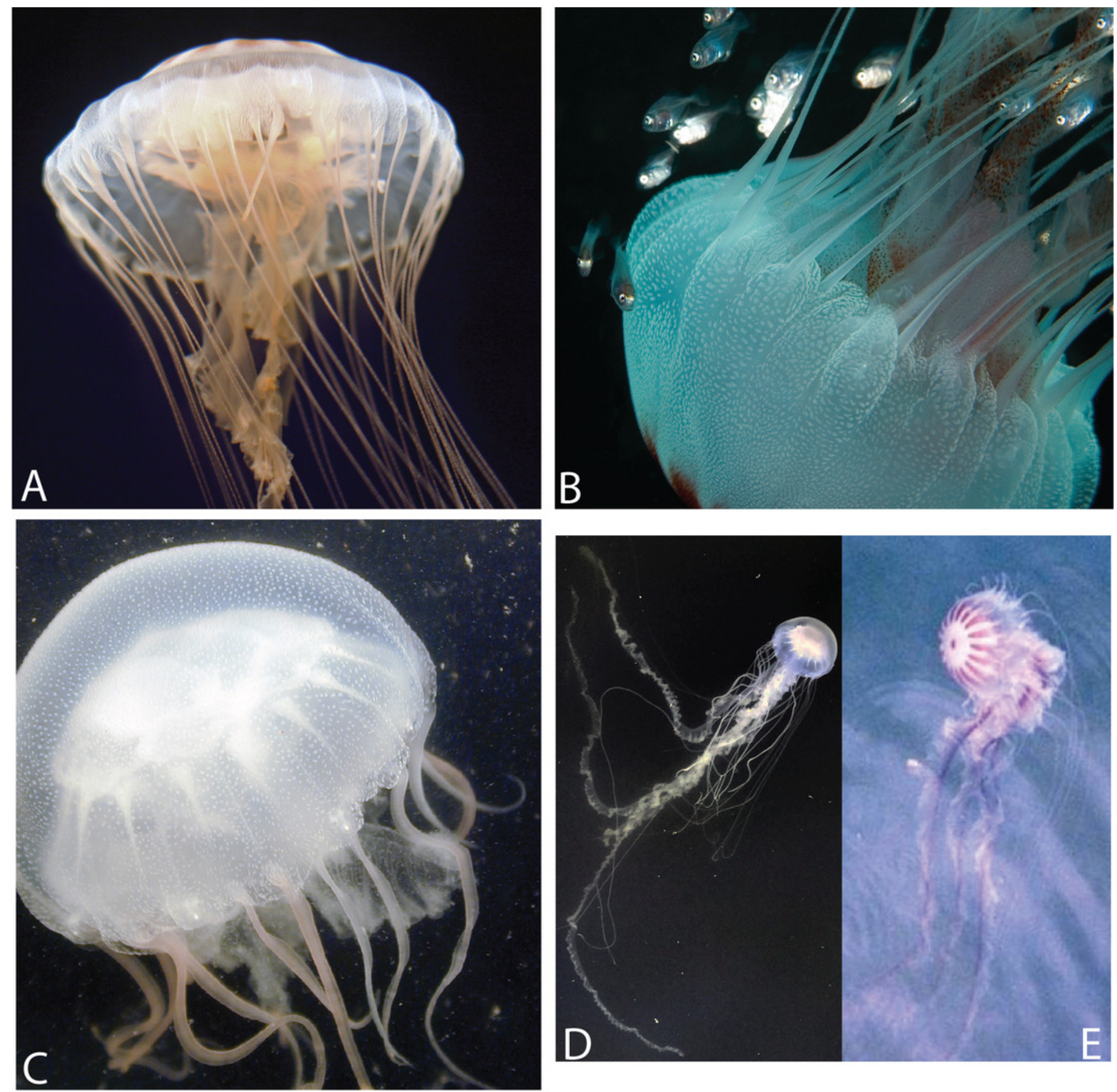


\section{Figure 4 (on next page)}

\section{Pelagiidae COI Phylogeny}

Bayesian Inference (BI) COI tree reconstructed from CLUSTAL alignment using Mr. Bayes v3.2.4 and applying the GTR $+I+G$ model of sequence evolution. Numbers adjacent to branches show bootstrap support if $\geq 0.70$ (presented as a percentage), followed by bootstrap support from maximum likelihood (ML) analysis if $\geq 50 \%$. ML phylogeny was reconstructed using PhyML v3.0 (Guindon et al. 2010) applying the TPM2uf+I+G model of sequence evolution (-Inl 5451.81154) as determined by jMODELTEST v2.1.7 (Darriba et al. 2012). Abbreviations refer to Tables 1-2. Specific identification to the right of the tree indicates final species designations. Clades colored in gray were originally identified as $C$. quinquecirrha. Norfolk (VA) individuals NF1-NF3 were identified as white Chesapeake Bay color morph and individuals NF4-NF5 as red-striped Chesapeake Bay color morph (Figure 3DE). 


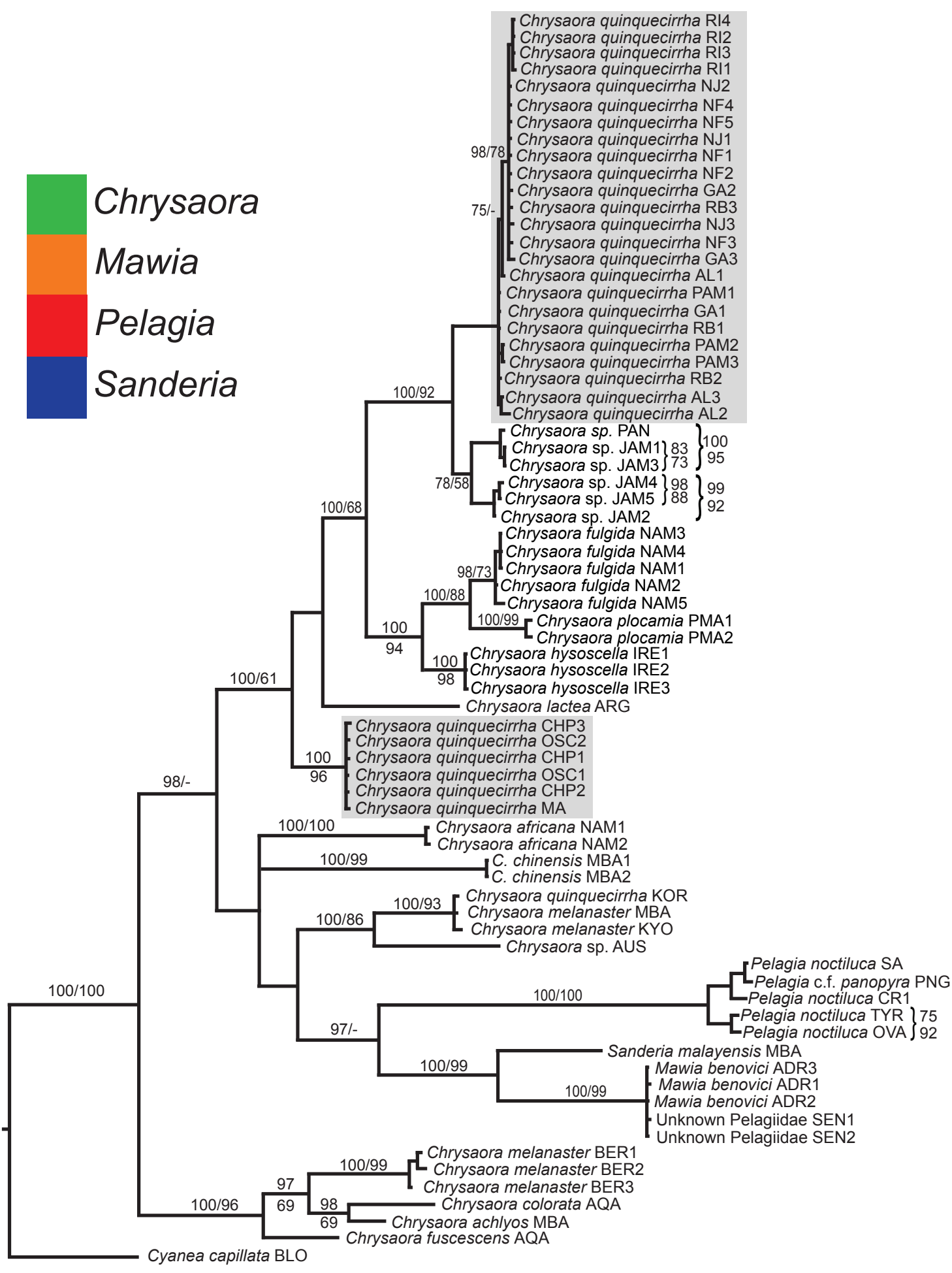

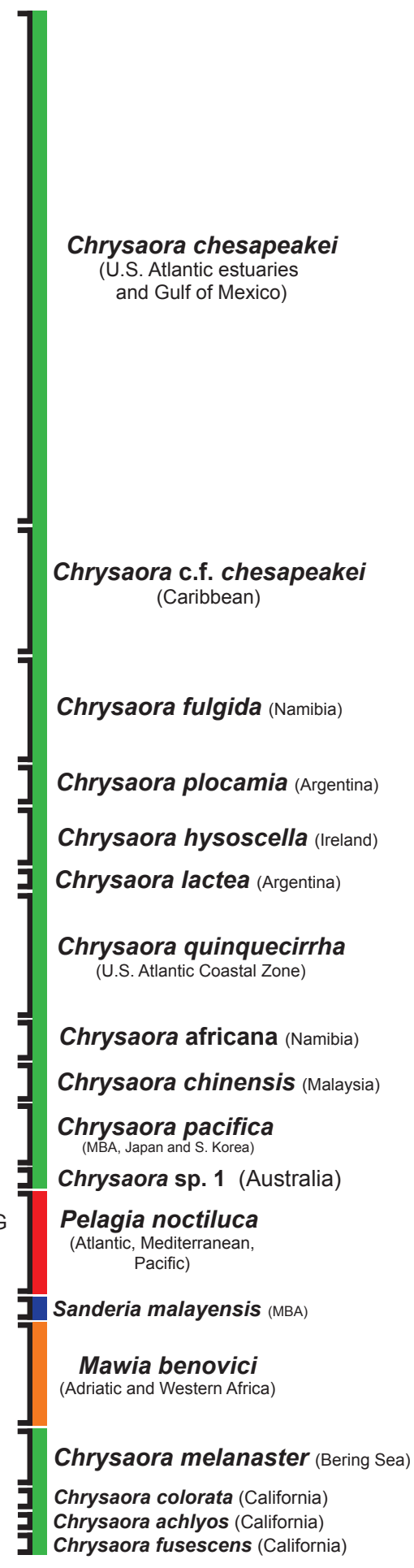




\section{Figure 5 (on next page)}

Pelagiidae 16S Phylogeny

Bayesian Inference (BI) 16S tree reconstructed from MAFFT alignment using Mr. Bayes v3.2.4 and applying the GTR $+\mathrm{I}+\mathrm{G}$ model of sequence evolution. Numbers adjacent to branches show bootstrap support if $\geq 0.70$ (presented as a percentage), followed by bootstrap support from maximum likelihood (ML) analysis if $\geq 50 \%$. ML phylogeny was reconstructed using PhyML v3.0 (Guindon et al. 2010) applying the TIM2+I+G model of sequence evolution (-InI 3641.97519) as determined by jMODELTEST v2.1.7 (Darriba et al. 2012) . Gray arrows indicate nodes that are alternated in the ML tree. Abbreviations refer to Tables 1-2. Specific identification to the right of the tree indicates final species designations. Clades colored in gray were originally identified as C. quinquecirrha s.I. Norfolk (VA) individuals NF1-NF3 were identified as white morph and individuals NF4-NF5 as red-striped bell morphs (Figure 3D-E). 


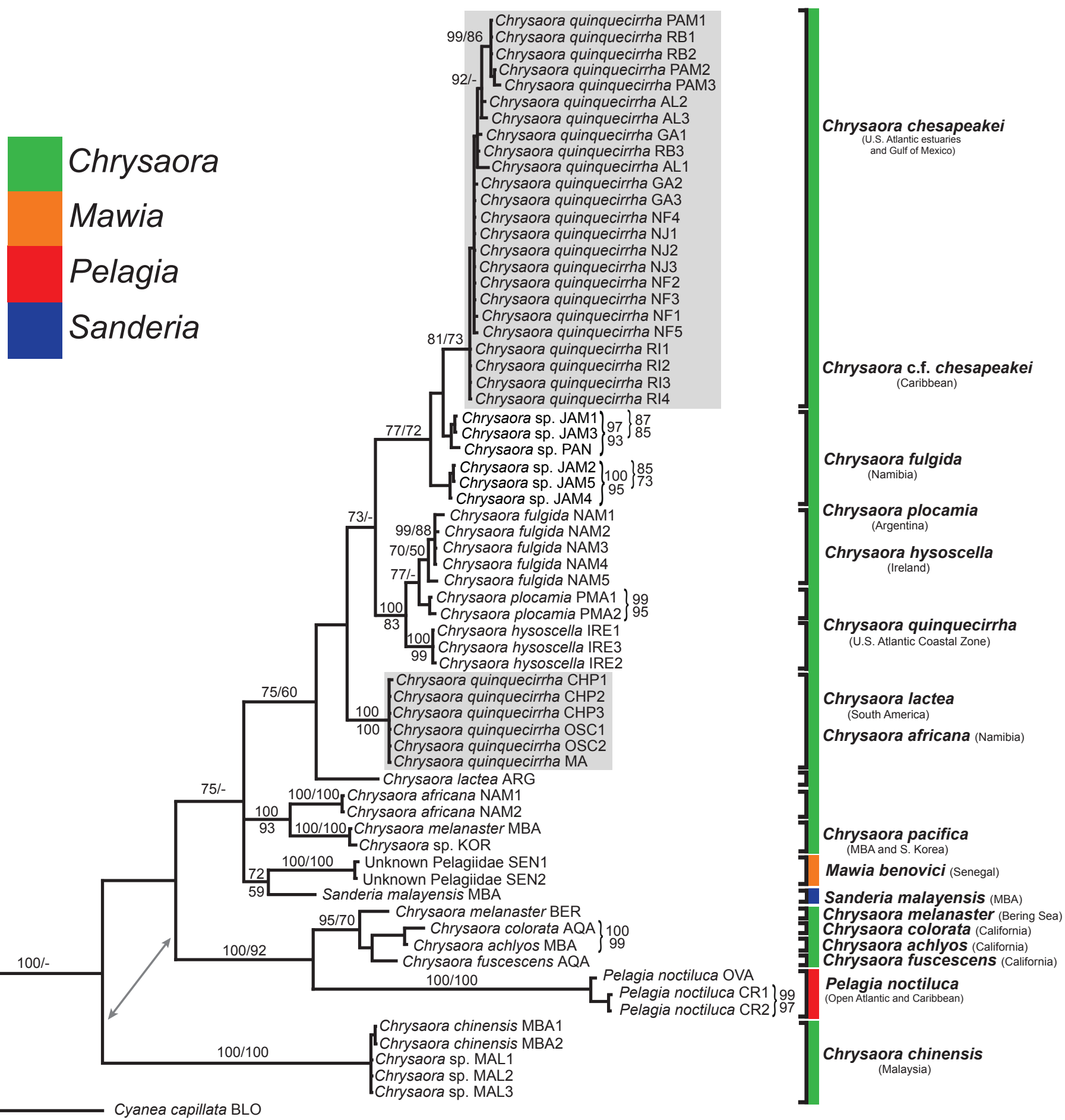




\section{Figure 6 (on next page)}

Pelagiidae 28S Phylogeny

Bayesian Inference (BI) 28S tree reconstructed from MAFFT alignment using Mr. Bayes v3.2.4 and applying the GTR $+\mathrm{I}+\mathrm{G}$ model of sequence evolution. Numbers adjacent to branches show bootstrap support if $\geq 0.70$ (presented as a percentage), followed by bootstrap support from maximum likelihood (ML) analysis if $\geq 50 \%$. ML phylogeny was reconstructed using PhyML v3.0 (Guindon et al. 2010) applying the TrNef+I+G model of sequence evolution (-Inl 3817.02691) as determined by jMODELTEST v2.1.7 (Darriba et al. 2012). Specific identification to the right of the tree indicates final species designations. Clades colored in gray were originally identified as $C$. quinquecirrha. 


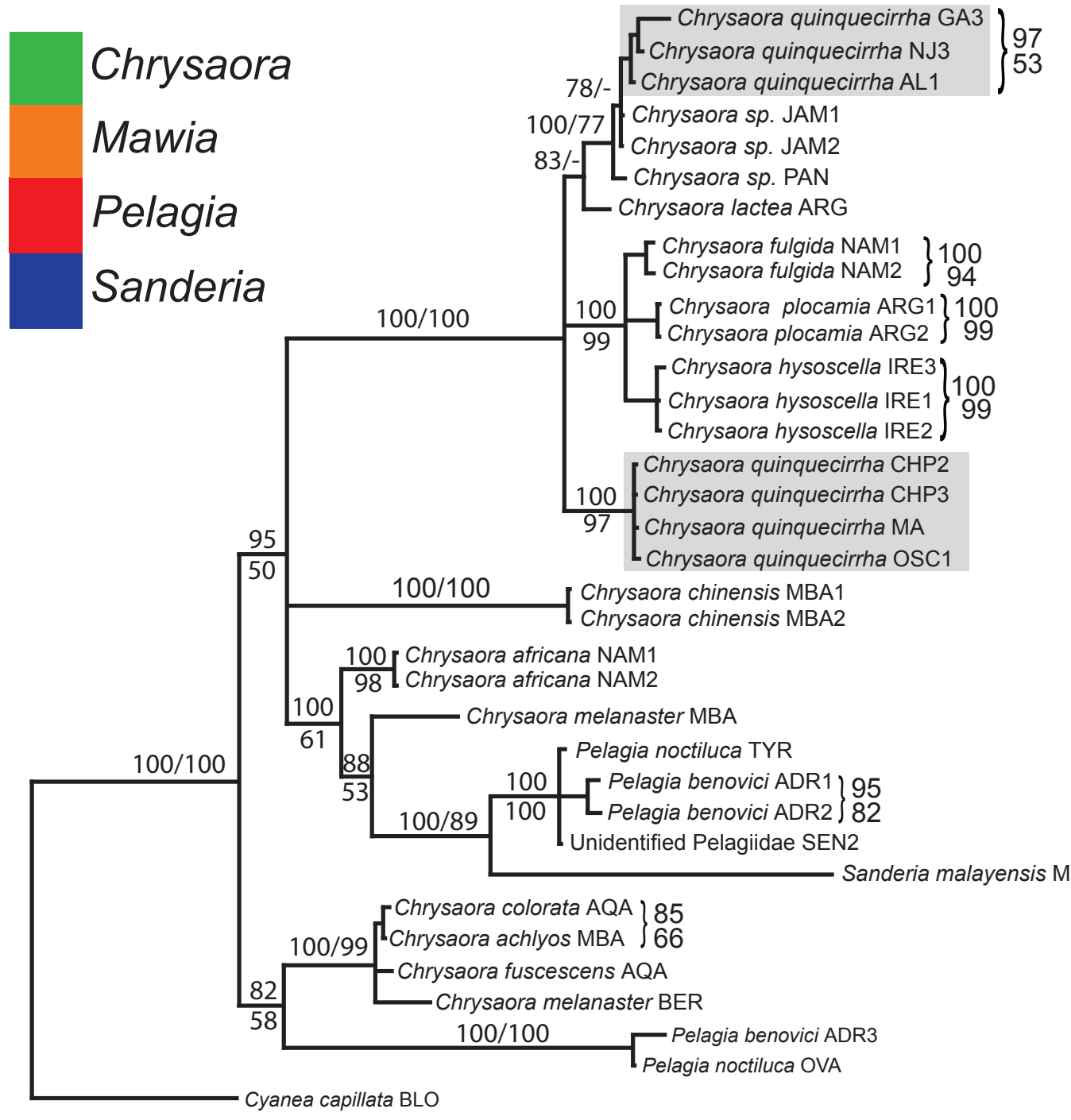

Chrysaora chesapeakei (U.S. Atlantic estuaries and Gulf of Mexico)

Chrysaora c.f. chesapeakei (Caribbean)

Chrysaora lactea (Argentina)

Chrysaora fulgida (Namibia)

Chrysaora plocamia (Argentina)

Chrysaora hysoscella (Ireland)

Chrysaora quinquecirrha (U.S. Atlantic Coastal Zone)

\section{Chrysaora chinensis} (Malaysia)

Chrysaora africana (Namibia)

Chrysaora pacifica (MBA)

Mawia benovici

(Senegal and Adriatic)

Pelagia noctiluca (Medterranean)

Sanderia malayensis (MBA)

Chrysaora colorata (California) Chrysaora achlyos (California) Chrysaora fusescens (California) Chrysaora melanaster (Bering Sea)

Mawia benovici (Adriatic) Pelagia noctiluca (Open Atlantic) 
Figure 7 (on next page)

Pelagiidae Combined Phylogeny

Bayesian Inference (BI) tree of the combined dataset applying the $\mathrm{GTR}+\mathrm{I}+\mathrm{G}$ model of sequence evolution. Numbers adjacent to branches show bootstrap support if $\geq 0.70$ (presented as a percentage), followed by bootstrap support from maximum likelihood (ML) analysis if $\geq 50 \%$. ML phylogeny was reconstructed using PhyML v3.0 (Guindon et al. 2010) applying the GTR+I+G model of sequence evolution (-Inl 11924.23655) as determined by jMODELTEST v2.1.7 (Darriba et al. 2012). Specific identification to the right of the tree indicates final species designations. Clades colored in gray were originally identified as $C$. quinquecirrha. 


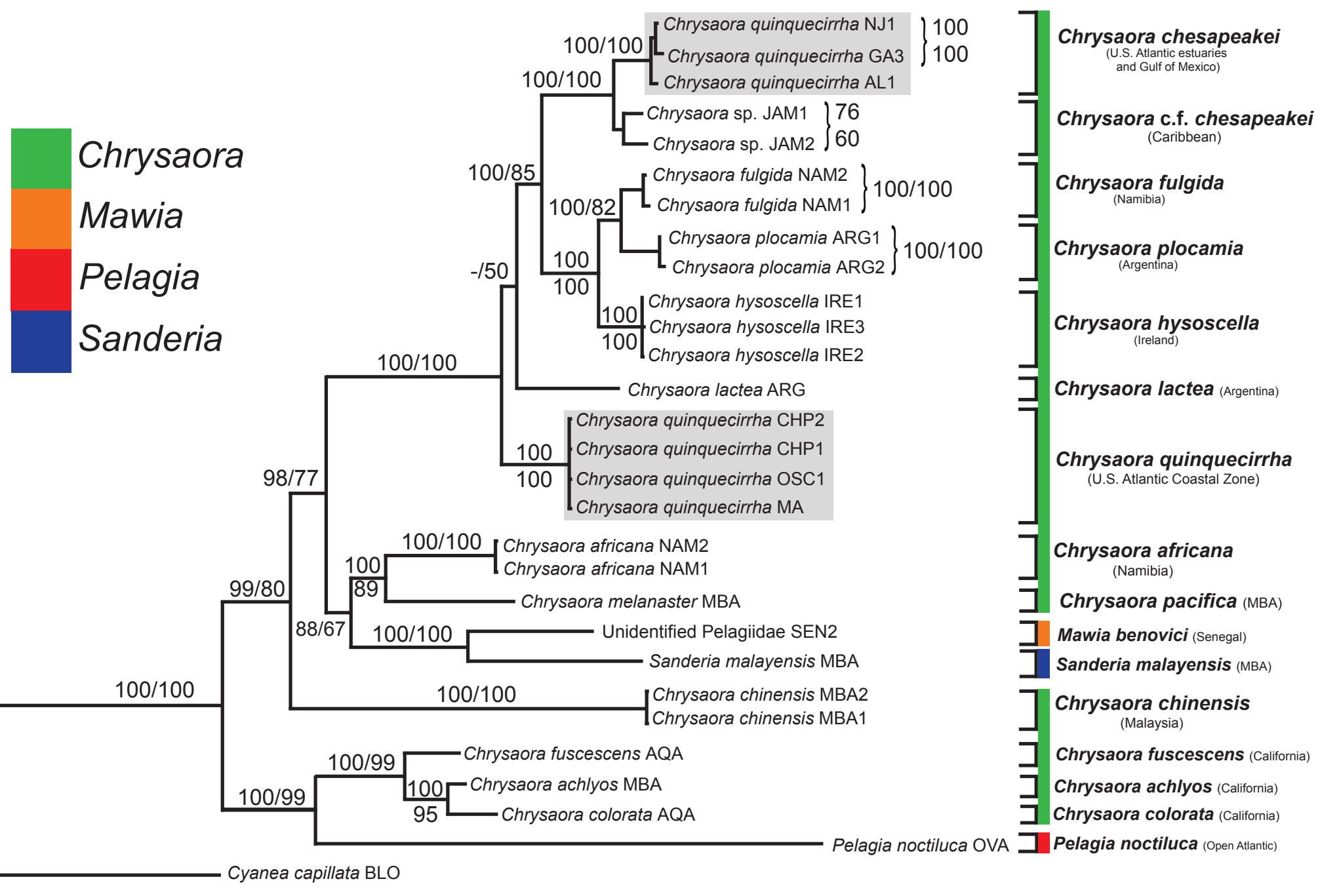

0.04 


\section{Figure 8 (on next page)}

Morphological evidence separating C. quinquecirrha and C. chesapeakei

A) Tentacle counts. Graph represents tentacles per octant against bell diameter $(\mathrm{mm})$ for field collected and museum specimens. Squares represent animals taken from estuarine Atlantic and Gulf of Mexico regions ( $C$. chesapeakei), while circles represent animals taken from coastal Atlantic regions (C. quinquecirrha). All animals with 165 sequences matching the $C$. chesapeakei clade appear in red, while those whose sequences matched the $C$. quinquecirrha clade appear in blue. B) Maximum oral arm measurements. Graph represents maximum oral arm length against bell diameter $(\mathrm{mm})$ for field-collected and museum specimens. Squares represent animals taken from U.S. Atlantic estuaries and the Gulf of Mexico ( $C$. chesapeakei), while circles represent animals taken from coastal Atlantic regions (C. quinquecirrha). Only animals with fully intact and extended oral arms were included. All animals with 165 sequences matching the $C$. chesapeakei clade appear in red, while those whose sequences matched the $C$. quinquecirrha clade appear in blue. C) Average size measurements for holotrichous A-isrohiza nematocysts (length vs. width), based on 10 nematocysts per. Error bars represent $95 \%$ confidence intervals ( $2 *$ standard error). Squares represent nematocysts from estuarine Atlantic and Gulf of Mexico medusae (C. chesapeakei), while circles represent nematocysts from coastal Atlantic medusae (C. quinquecirrha). Photograph of an average sized A-isorhiza from $C$. quinquecirrha appears on the left and a photograph of an average size A-isorhiza from C. chesapeakei appears on the right. Scale bars $=10$ um. Photographs have been resized so that all error bars are the same size on the page to allow size comparisons. All animals with 165 sequences matching the $C$. chesapeakei clade appear in red, while those whose sequences matched the $C$. quinquecirrha clade appear in blue. Triangles represent average values from Papenfuss (1936) for morphs identified as Dactylometra quinquecirrha (gray) or Dactylometra quinquecirrha var. chesapeakei (white). 
A

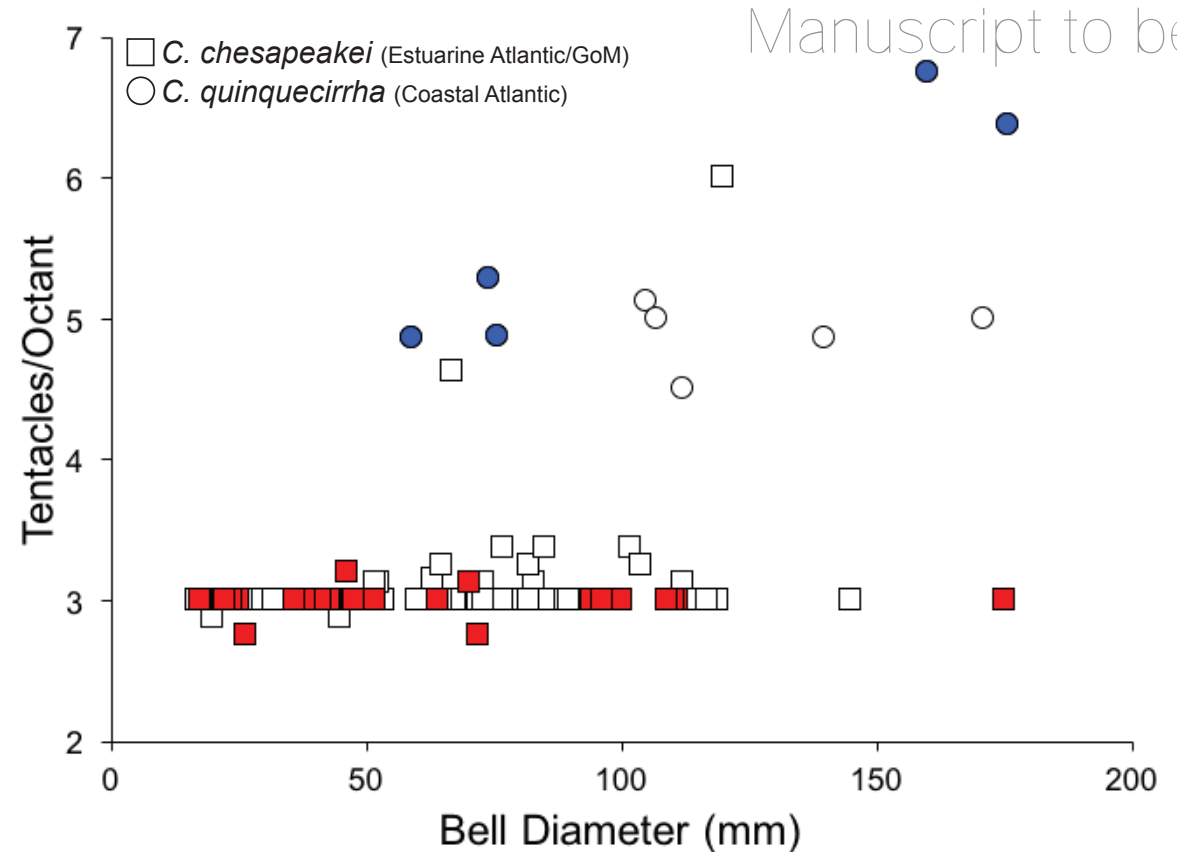

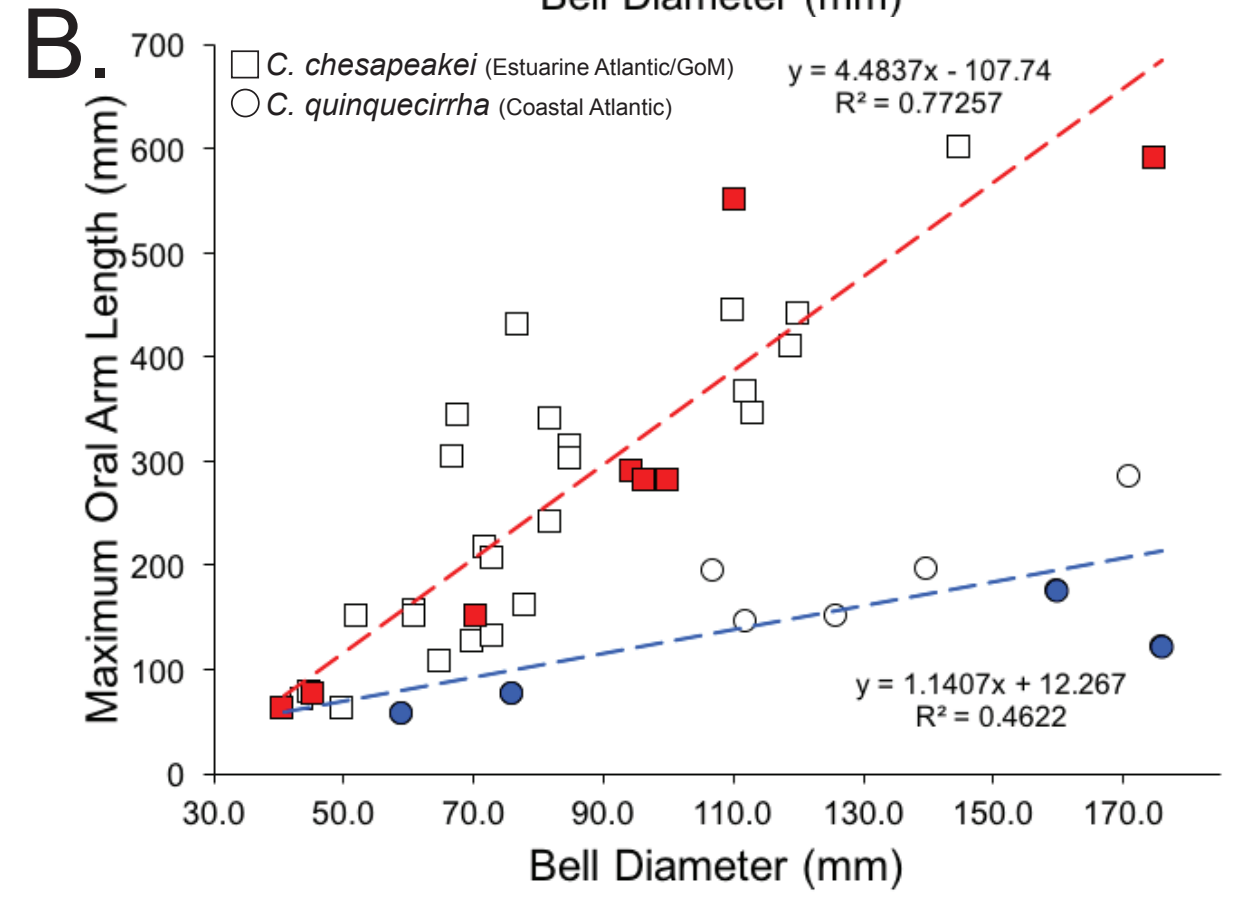

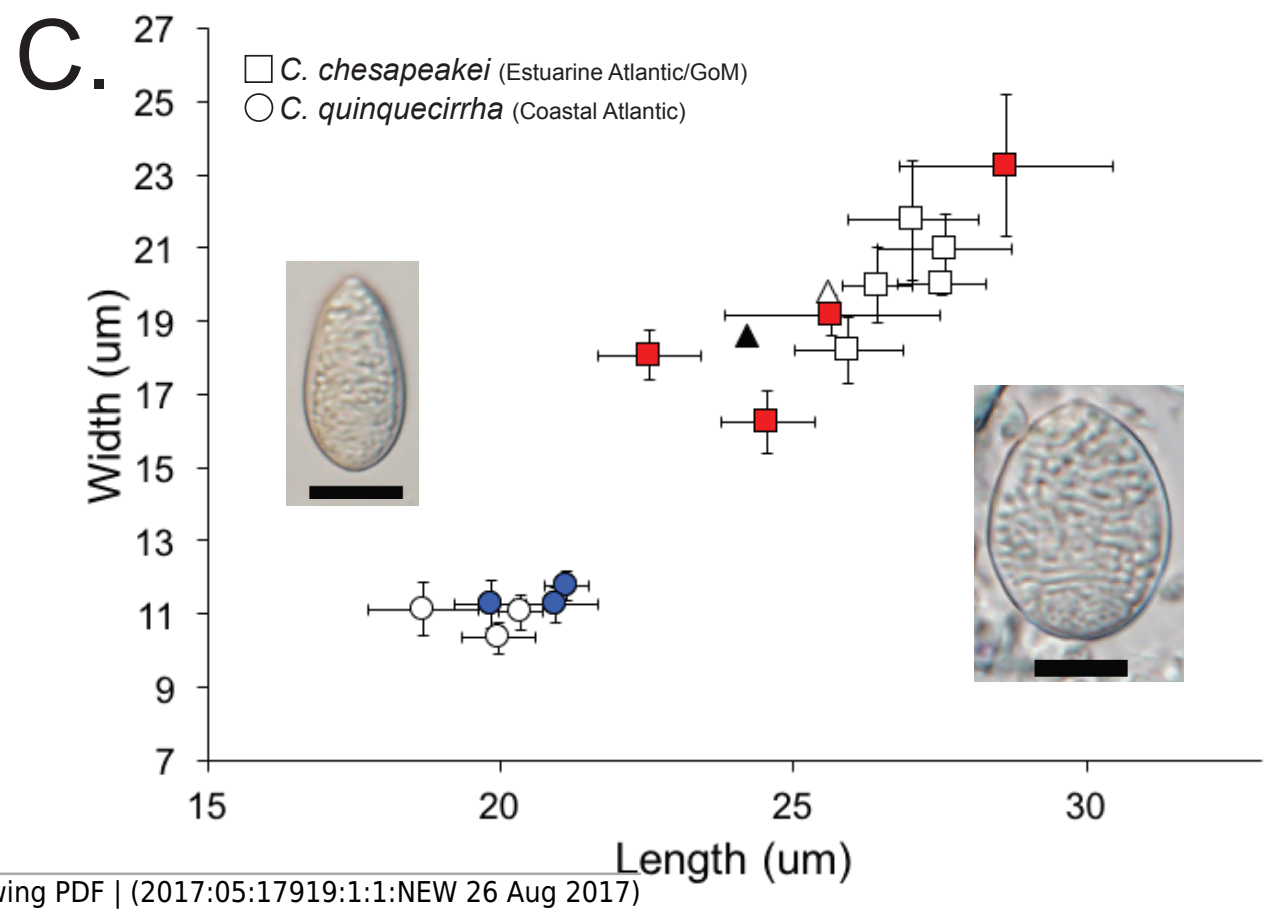




\section{Figure 9 (on next page)}

Pelagiidae Evolution

Pelagiidae Evolution. Cladograms showing genus-level relationships within the Pelagiidae family. Colors represent individual genera as shown. A) Gershwin and Collins (2002); B) Morandini and Marques (2010); C) Avian et al. (2016): DNA analysis based on nuclear 28S; D) Avian et al. (2016): morphological analyses only; E) This study: Combined DNA analysis using sequence data from COI, 165 and 28S. *In Avian et al. (2016), this sequence is marked as Chrysaora sp. AY920779. This sequence is included in our analysis and is part of the clade that we call Chrysaora c.f. chesapeakei. ^We include the 285 phylogeny from Avian et al. (2016) because it has more species than their combined analysis but their generic conclusions are identical. Note that all previous hypotheses include a monophyletic Chrysaora. 


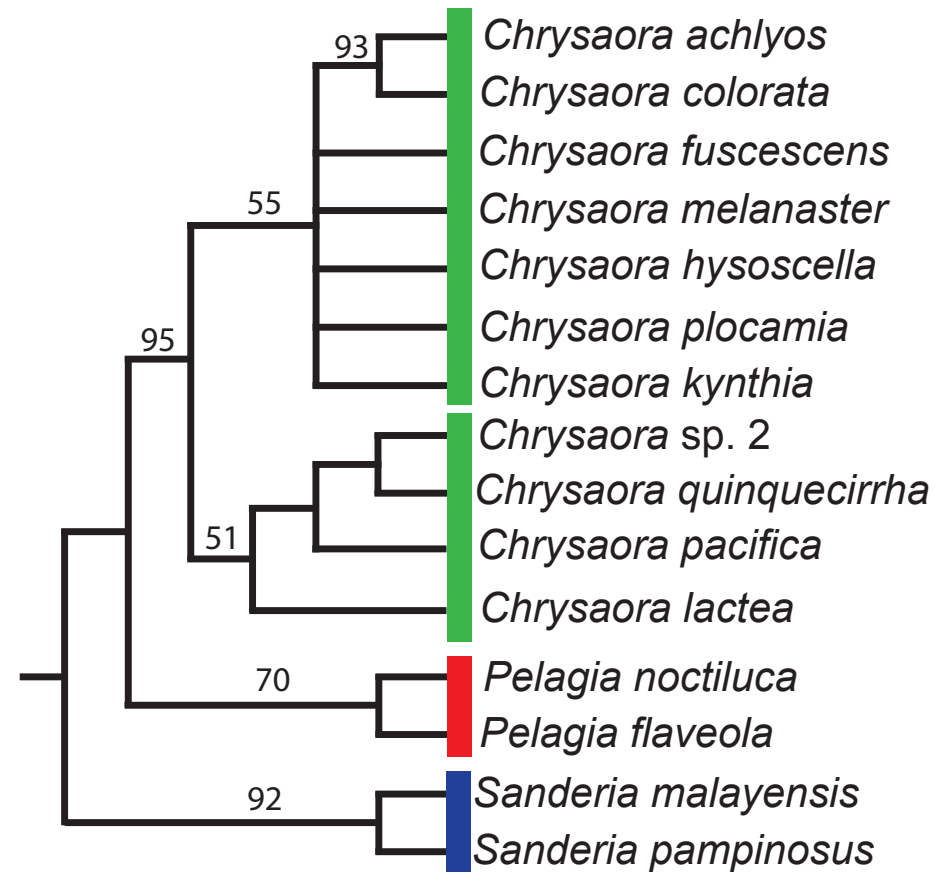

A. Gershwin and Collins, 2002

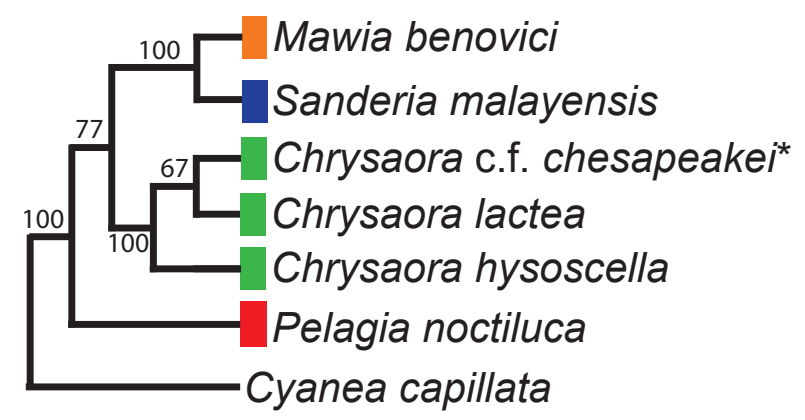

C. Avian et al., 2016 (28S DNA analysis^)

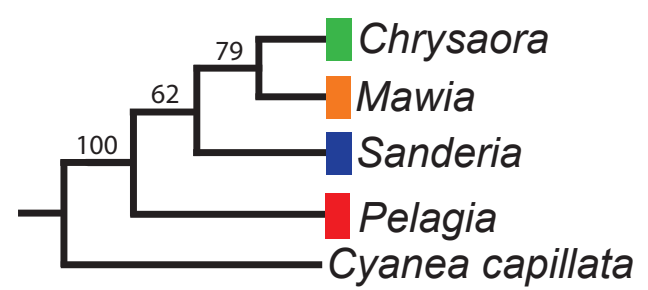

D. Avian et al., 2016 (morphology)

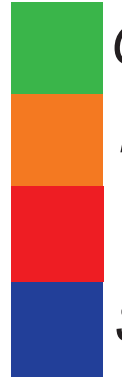

Chrysaora

Mawia

Pelagia

Sanderia

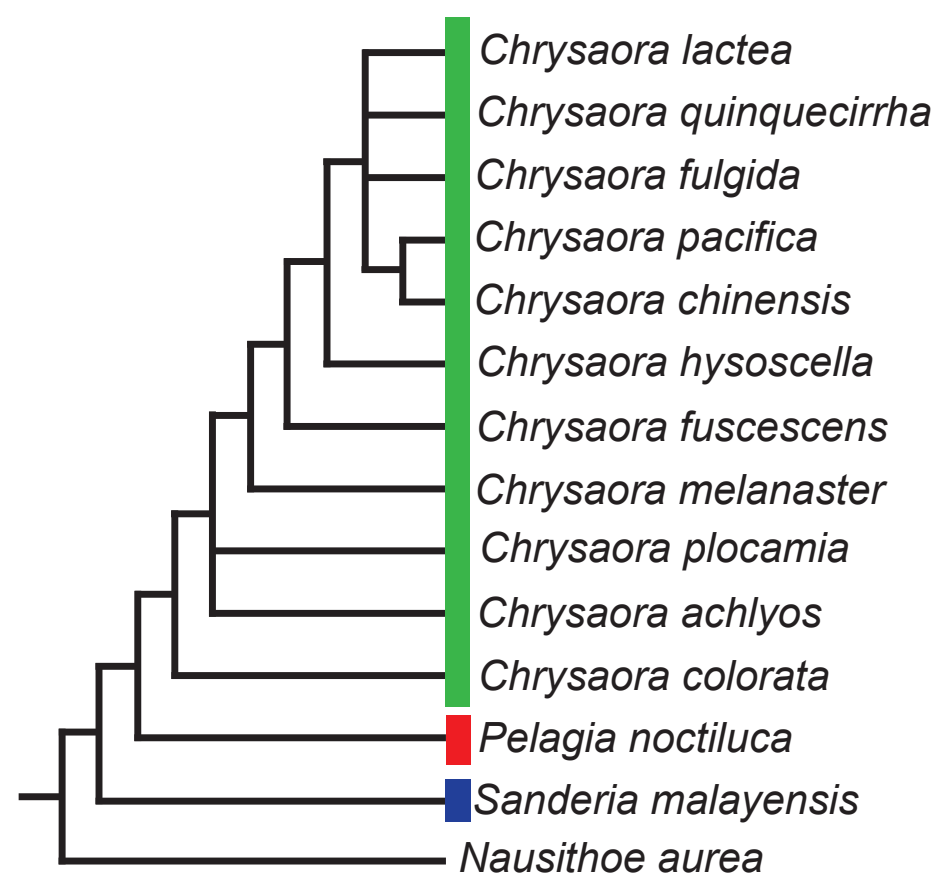

B. Morandini and Marques, 2010

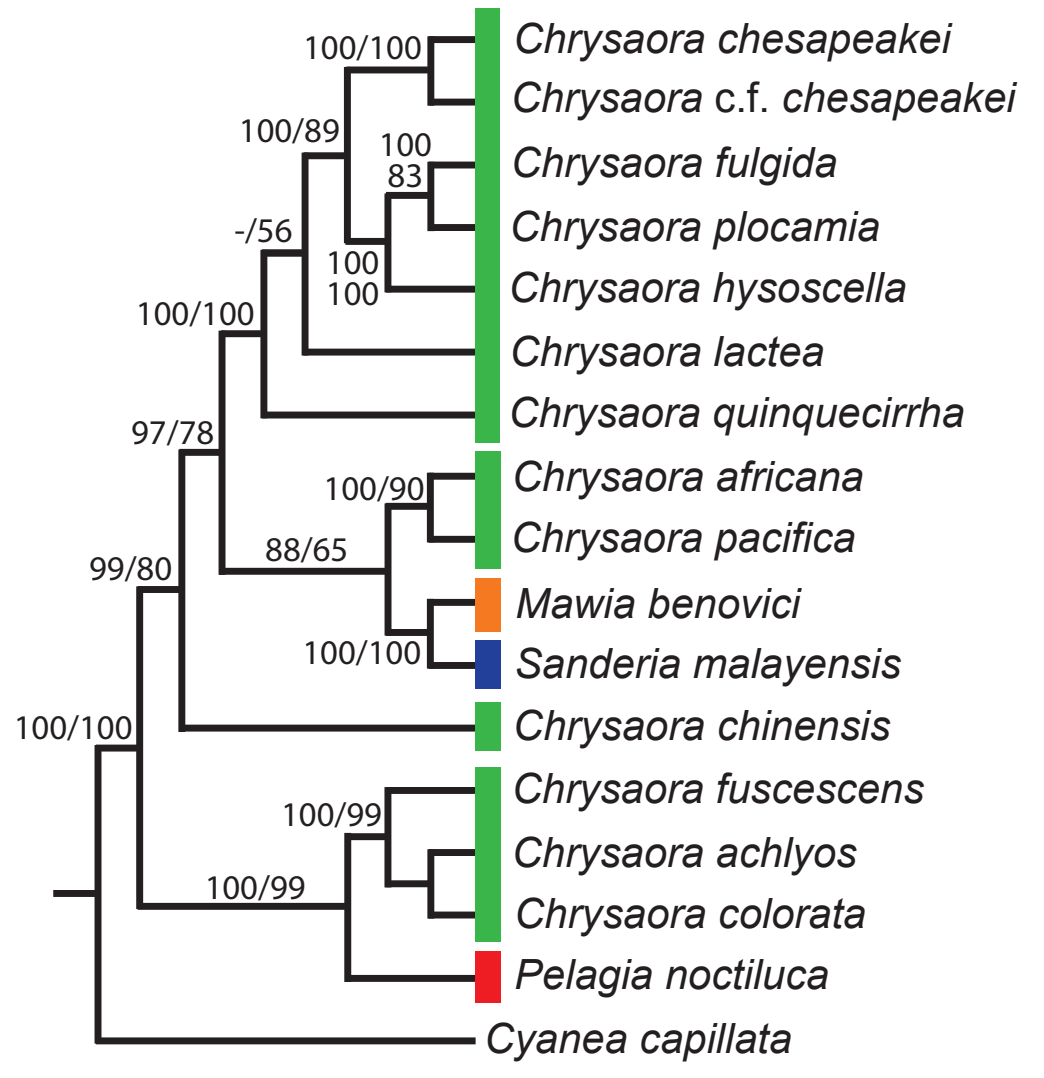

E. This study (combined DNA analyses) 